\title{
SYNTHESIS, MOLECULAR MODELING, AND QUANTITATIVE STRUCTURE-ACTIVITY RELATIONSHIP STUDIES OF UNDEC-10-ENEHYDRAZIDE DERIVATIVES AS ANTIMICROBIAL AGENTS
}

\author{
MANJU KUMARI ${ }^{1}$, RAKESH NARANG ${ }^{1}{ }^{*}$, SURENDRA KUMAR NAYAK ${ }^{1}$, SACHIN KUMAR SINGH ${ }^{1}$, VIVEK GUPTA $^{1}$, \\ BALASUBRAMANIAN NARASIMHAN ${ }^{2}$
}

${ }^{1}$ Department of Pharmaceutical Chemistry, School of Pharmaceutical Sciences, Lovely Professional University, Phagwara - 144 401, Punjab, India. ${ }^{2}$ Department of Pharmaceutical Chemistry, Faculty of Pharmaceutical Sciences, Maharshi Dayanand University, Rohtak - 124 001, Haryana, India. Email: rakesh.15772@lpu.co.in

Received 14 July 2017, Revised and Accepted 25 July 2017

ABSTRACT

Objective: In recent years, an increasing frequency and severity of antimicrobial resistance to different antimicrobial agents, demands new remedies for the treatment of infections. Therefore, in this study, a series of undec-10-enehydrazide derivatives were synthesized and screened for in vitro activity against selected pathogenic microbial strains.

Methods: The synthesis of the intermediate and target compounds was performed by standard procedure. Synthesized compounds were screened for antimicrobial activity by tube dilution method. Molecular docking study of synthesized derivatives was also performed to find out their interaction with the target site of $\beta$-ketoacyl-acyl carrier protein synthase III, (FabH; pdb id:3IL7) by docking technique. Quantitative structure-activity relationship (QSAR) studies were also performed to correlate antimicrobial activity with structural properties of synthesized molecules.

Results: Antimicrobial screening results showed that compound 8 having benzylidine moiety with methoxy groups at meta and para position and compound 16 having 3-chloro-2-(3-flourophenyl)-4-oxoazetidine moiety was found to be most potent. QSAR studies revealed the importance of Randic topology parameter (R) in describing the antimicrobial activity of synthesized derivatives. Molecular docking study indicated hydrophobic interaction of deeply inserted aliphatic side chain of the ligand with FabH. The N-atoms of hydrazide moiety interacts with Ala246 and Asn247 through H-bonding. The $m$ - and $p$-methoxy groups form H-bond with water and side chain of Arg36, respectively.

Conclusion: Compound 8 having benzylidine moiety with methoxy groups at meta and para position and compound 16 having 3-chloro-2-(3flourophenyl)-4-oxoazetidine moiety was found to most potent antibacterial and antifungal compounds, respectively.

Keywords: Antibacterial, Antifungal molecular docking, Biological evaluation, Undec-10-enoic acid derivative.

(C) 2017 The Authors. Published by Innovare Academic Sciences PvtLtd. This is an open accessarticle under the CC BY license (http://creativecommons. org/licenses/by/4. 0/) DOI: http://dx.doi.org/10.22159/ajpcr.2017.v10s4.21344

\section{INTRODUCTION}

Antimicrobial resistance (AMR) is an increasingly serious health problem worldwide. It causes difficulty in the successful treatment and prevention of an ever-growing infectious disease, caused by bacteria, fungi, parasites, and viruses [1]. Due to resistant microbial strains, the cost of treatment is much more as compared to treatment caused by nonresistant strains. The treatment has to continue for the longer duration of time with additional diagnostic tests and comparatively higher cost of drugs $[2,3]$. Hence, AMR threat demands synthesis of new effective antibiotics against resistant microbial strains.

Undec-10-enoic (undecylenic acid) is 11 carbon straight chain unsaturated fatty acid, synthesized by cracking of castor oil under pressure. It is a natural fungicide, used for the treatment of skin infections such as athlete's foot, ringworm and jock itch. Undecylenic acid also has antiviral properties effective in skin infections caused by herpes simplex [4]. Reported data suggested that undec-10-enoic acid and their derivatives can make a complex with iron ions, which afford an effective mechanism to stop the bacterial growth [5]. Further, the previous studies performed by us revealed the significance of different acid derivatives, including undec-10-enoic hydrazide-hydrazone derivatives as antibacterial and antifungal agents [6-11]. Studies reported by various research groups also showed that hydrazide-hydrazone derivatives of different acids have wide range of biological activities, viz., antibacterial [12], antifungal [13], antitubercular [14], trypnocidal [15], antimalarial [16], antiviral [8], anti-inflammatory [17], and antitumor [18] activities. Isoniazid (antitubercular) [19], nifuroxazide (antidiarrheal and antitumor) [20], nifurtimox (antiamoebic) [21], furacin (antibiotic) [22], and furazolidone (antibacterial) [23] are hydrazide containing important biologically active drug molecules. Moreover, SAR studies indicated that substitution at a specific position in aromatic ring attached to hydrazide moiety and conversion of hydrazide moiety to hydrazone/pyrazole/oxadiazole/4-oxoazitidine based molecules affect the biological activity to a great extent $[9,24,25]$. Based on aforementioned observations and in continuation of our ongoing research program [6-11], hydrazide-hydrazone derivatives of undec-10-enoic were synthesized and evaluated for their antimicrobial activity against Escherichia coli, Bacillus subtilis, Staphylococcus aureus, Aspergillus niger, and Aspergillus fumigatus by tube dilution method.

Based on efficient predicting ability of quantitative structure-activity relationship (QSAR) method of closely related analogs [26] and to correlate antimicrobial activities with structural parameters of synthesized molecules, one-target QSAR (ot-QSAR) and multi-target QSAR (mt-QSAR) models were developed. Molecular docking studies were also carried out to understand the binding pattern and to support in vitro antimicrobial data of synthesized most active compound $[27,28]$. Automated docking technique was used to determine the orientation of inhibitors, bound in the active site of $\beta$-ketoacyl-acyl carrier protein synthase III (FabH; pdb id:3IL7) [29]. $\beta$-ketoacyl-acyl carrier protein synthase encoded by the fabH gene is reported to catalyze the first 
elongation reaction (Claisen condensation) of type II fatty acid synthesis and responsible for the synthesis of long chain fatty acid structures, present in bacteria and fungi [30-32].

\section{EXPERIMENTAL}

Progress and completion of the reaction were monitored by thin layer chromatography (TLC) on silica gel sheets (Merck silica gel-G). Melting points were determined in open glass capillaries on Popular India melting point apparatus. ${ }^{1} \mathrm{H}$ nuclear magnetic resonance $\left({ }^{1} \mathrm{H}\right.$ NMR) spectra were recorded on Bruker Avance II 400 NMR spectrometer $(400 \mathrm{MHz})$ at $298 \mathrm{~K}$, in appropriate deuterated solvents. Chemical shifts were reported as $\delta(\mathrm{ppm})$ relative to tetramethylsilane as an internal standard. Infrared spectra (IR) were recorded as $\mathrm{KBr}$ pellet on Shimadzu FTIR spectrometer. The wave number is given in $120 \mathrm{~cm}^{-1}$. Mass spectra were recorded on Waters Micromass Q-TOF Micro instrument.

Synthetic procedure for synthesis of undecylenic acid hydrazide derivatives (Schemes 1 and 2)

Synthesis of methyl undec-10-enoate (2) from undecylenic acid (1) An ethanolic mixture of $(0.05 \mathrm{~mol})$ of undecylenic acid (1) was refluxed in the presence of concentrated sulfuric acid (4-5 drops) for $4 \mathrm{hrs}$. The completion of reaction was confirmed by TLC. The excess of acid was neutralized with sodium bicarbonate. Then, synthesized crude ester was extracted by adding diethyl ether and water in separating funnel. Ester (2) was obtained by evaporating diethyl ether layer. Moisture of ester was removed by sodium sulphate. Synthesized crude ester was recrystallized using ethanol.

\section{Synthesis of undec-10-ene hydrazide (3) from methyl undec-10- enoate (2)}

Solution of methyl undec-10-enoate $(0.02 \mathrm{~mol})$ and hydrazine hydrate $(0.058 \mathrm{~mol})$ was refluxed in ethanol for $14 \mathrm{hrs}$. Reaction mixture was cooled and precipitate of undec-10-enehydrazide was collected and recrystallized from ethanol.

Synthesisofbenzylideneundec-10-enehydrazidederivatives (4-13) from undec-10-ene hydrazide (3)

Mixture of undec-10-ene hydrazide (3) (0.005 mol) and equimolar amount of appropriate substituted benzaldehydes/acetophenone in ethanol was refluxed for 7-8 hrs. The excess of ethanol was evaporated. Precipitated compounds (4-13) were filtered off and washed with hexane.

Synthesis of $\mathrm{N}$-(3-chloro-2-oxo-4-phenylazetidin-1-yl)undec10-enamide derivatives (14-16) from benzylideneundec-10enehydrazide (4-6)

Chloroacetyl chloride $(0.01 \mathrm{~mol})$ was added to a mixture of triethylamine $(0.01 \mathrm{~mol})$ and benzylideneundec-10-enehydrazide $(0.01 \mathrm{~mol})$ in 1 , 4-dioxane $(40 \mathrm{ml})$ with stirring at $0-5^{\circ} \mathrm{C}$ for $1 \mathrm{hr}$ followed by stirring for $3 \mathrm{hrs}$ at room temperature. The completion of reaction was checked by TLC. Excess solvent was evaporated and synthesized azetidinone derivatives (14-16) were washed with hexane. Mixture of both form of stereoisomer was obtained.

Synthesis of 3-methyl-1-(undec-10-enoyl)-1H-pyrazol-5(4H)-one (17) from undec-10-ene hydrazide (3)

A solution of undec-10-enehydrazide (3) (0.005 mol) and ethyl acetoacetate $(0.08 \mathrm{~mol})$ in ethanol was refluxed for $16 \mathrm{hrs}$. Reaction mixture was cooled and the precipitates of 3-methyl-1-(undec-10enoyl)- $1 H$-pyrazol-5(4H)-one (17) was filtered off and washed with mixture of toluene and ethanol (4.5: 0.5).

Synthesis of 2-methyl-5-(undec-10-en-1-yl)-1,3,4-oxadiazole (18) from undec-10-ene hydrazide (3)

Ethanolic solution of undec-10-enehydrazide (3) (0.005 mol) was refluxed for $8 \mathrm{hrs}$ with acetic anhydride $(0.048 \mathrm{~mol})$. Completion of the reaction was confirmed by TLC. Final liquid product (18) was obtained after evaporation of excess of solvent on water bath.

Synthesis of $N^{\prime}$-acetylundec-10-enehydrazide (19) from undec10-ene hydrazide (3)

Ethanolicsolution ofundec-10-enehydrazide(3) $(0.005 \mathrm{~mol})$ was refluxed for $8 \mathrm{hrs}$ in acetic acid $(0.049 \mathrm{~mol})$ and acetic anhydride $(0.049 \mathrm{~mol})$. Reaction mixture was cooled and the precipitates of $N^{\prime}$-acetyldec-9enehydrazide (19) was filtered off and recrystallized with ethanol.

\section{Spectral data}

Methyl undec-10-enoate (2)

Bp $\left({ }^{\circ} \mathrm{C}\right)$ 103-108; yield $80 \%$; ${ }^{1} \mathrm{H}$ NMR (400 $\left.\mathrm{MHz}, \mathrm{CDCl}_{3}\right) \delta$ : 5.57-5.67 (m, $\left.1 \mathrm{H}, \mathrm{C}_{10}\right), 4.73-4.83(\mathrm{~d}, 2 \mathrm{H}), 3.48(\mathrm{~s}, 3 \mathrm{H}), 2.09-2.15(\mathrm{q}, 2 \mathrm{H}), 1.85-1.90$ $(\mathrm{t}, 2 \mathrm{H}), 1.42-1.47(\mathrm{~m}, 2 \mathrm{H}), 1.06-1.24(\mathrm{~m}, 10 \mathrm{H})$. IR (KBr pellets) $\mathrm{cm}^{-1}$ : 3076.56 (C-H str., alkenes), 2928.04 (C-H str., aliphatic), 1741.78 (C=0 str.), 1641.48 (C=C str., alkenes), 1460.16 (C-H bending, aliphatic), 993.37 (C-H bending, alkenes).

\section{Undec-10-ene hydrazide (3)}

Mp $\left({ }^{\circ} \mathrm{C}\right)$ 88-93; yield 72\%; ${ }^{1} \mathrm{H}$ NMR (400 MHz, $\left.\mathrm{CDCl}_{3}\right) \delta: 7.49(\mathrm{~s}, 1 \mathrm{H})$, 5.68-5.78 (m, 1H), 4.83-4.94 (d, 2H), 3.88 (s, 2H), 2.07-2.11 (t, 2H), 1.93$1.99(\mathrm{~m}, 2 \mathrm{H}), 1.18-1.31(\mathrm{~m}, 10 \mathrm{H})$. IR (KBr pellets) $\mathrm{cm}^{-1}: 3317.61(\mathrm{NH}$ str.), 3045.70 (C-H str., alkenes), 2920.32 (C-H str., aliphatic), 1664.27 ( $\mathrm{C}=\mathrm{C}$, alkenes), 1631.83 ( $\mathrm{C}=0 \mathrm{O}$ str.), 1537.32 ( $\mathrm{NH}$ bending), 1462.02 (C-H bending, aliphatic), 912.36 (C-H bending, alkenes).

\section{$N^{\prime}$-benzylideneundec-10-enehydrazide (4)}

Mp $\left({ }^{\circ} \mathrm{C}\right)$ 88-93; yield $64 \%$; ${ }^{1} \mathrm{H}$ NMR (400 MHz, dimethyl sulfoxide [DMSO]): $\delta 10.72$ (s, NH), $9.80(\mathrm{~s}, 1 \mathrm{H}), 7.52-7.83(\mathrm{~m}, 5 \mathrm{H}), 5.00-5.83(\mathrm{~m}$, $1 \mathrm{H}), 4.90-4.99(\mathrm{~m}, 2 \mathrm{H}), 2.00-2.78(\mathrm{t}, 2 \mathrm{H}), 1.92(\mathrm{~m}, 2 \mathrm{H}), 1.25-1.92(\mathrm{q}, 2 \mathrm{H})$, 1.18-1.23 (m, 10H),. IR (KBr pellets) $\mathrm{cm}^{-1}: 3443.05$ (NH str.), 3190.37 (C-H aromatic) 3022.55 (C-H str., alkenes), 2918.40 (C-H str., alkane), 2364.81 ( $\mathrm{C}=\mathrm{N}$, nitriles), 1668.48 ( $\mathrm{C}=0$ str.), 1649.19 ( $\mathrm{C}=\mathrm{C}$ str. alkenes), 1606.76 and 1465.95 ( $C=C$, aromatic), 958.65(C-H bending, alkenes), 1448.59 (C-H bending, alkane) MS ES+ (ToF): m/z $287.2\left[\mathrm{M}^{+}+1\right]$.

\section{$N^{\prime}$-(3-nitrobenzylidene) undec-10-enehydrazide (5)}

Mp $\left({ }^{\circ} \mathrm{C}\right)$ 115-120; yield $72 \%$; ${ }^{1} \mathrm{H}$ NMR $\left(400 \mathrm{MHz}, \mathrm{CDCl}_{3}\right) \delta: 10.52$ (s, $1 \mathrm{H}), 8.27-8.2(\mathrm{~d}, 2 \mathrm{H}), 7.92(\mathrm{~s}, 1 \mathrm{H}), 7.82-7.84(\mathrm{~d}, 2 \mathrm{H}), 5.75-5.83(\mathrm{~m}, 1 \mathrm{H})$, 4.95-5.01 (d, 1H), 4.91-4.94 (d, 1H), 2.77-2.81 (t, 2H), $2.10(\mathrm{q}, 2 \mathrm{H}), 1.71-$ $1.78(\mathrm{~m}, 2 \mathrm{H}), 1.23-1.46(\mathrm{~m}, 10 \mathrm{H})$. IR (KBr pellets) $\mathrm{cm}^{-1}: 3446.91(\mathrm{NH}$ str.), 3115.14 (C-H str., aromatic), 2924.18 (C-H str., alkenes), 2850.88 (C-H str., alkane), 2360.95 (C=N str.), 1668.48 (C=0 str.), 1583.61 (NH bending), 1521.89 and 1338.64 ( $N=0$ str.), 1597.11 and 1467.88 ( $\mathrm{C}=\mathrm{C}$, aromatic).

\section{$N^{\prime}$-(3-fluorobenzylidene)undec-10-enehydrazide (6)}

$\mathrm{Mp}\left({ }^{\circ} \mathrm{C}\right)$ 210-215; yield 50\%; ${ }^{1} \mathrm{H}$ NMR (400 MHz, $\left.\mathrm{CDCl}_{3}\right) \delta$ : $9.67(\mathrm{~s}, 1 \mathrm{H})$, 7.31-7.37 (d, 2H), $7.21(\mathrm{~s}, 1 \mathrm{H}), 6.87-6.91(\mathrm{~d}, 2 \mathrm{H}), 5.60-5.63(\mathrm{~m}, 1 \mathrm{H})$, 4.65-4.80 (d, $1 \mathrm{H}), 4.72-4.75(\mathrm{~m}, 1 \mathrm{H}), 2.70-2.75(\mathrm{t}, 2 \mathrm{H}), 2.00(\mathrm{q}, 2 \mathrm{H})$, 1.62-1.67 (m, 2H), 1.24-1.49 (m, 10H). IR (KBr pellets) $\mathrm{cm}^{-1}: 3443.05$ (NH str.), 2926.11 (C-H str., alkenes), 2852.81 (C-H str., alkane), 2364.81 ( $\mathrm{C}=\mathrm{N}$, nitriles), 1400.37 and 1321.28 (C-H bending, alkane), 1633.76 (C=0 str.), 1294.28 (C-F), 964.44 (C-H bending, alkenes), 794.70 (C-H bending, aromatic).

\section{$N^{\prime}$-(3, 4-dimethoxybenzylidene)undec-10-enehydrazide (8)}

Mp $\left({ }^{\circ} \mathrm{C}\right)$ 210-215; yield 50\%; ${ }^{1} \mathrm{H}$ NMR (400 MHz, DMSO): $\delta 9.80$ (s, NH), 7.02-7.88 (m, 4H), 5.71-5.80 (m, 1H), 4.89-4.99 (d, 2H), 2.17-2.26 (m, $2 \mathrm{H}), 1.58-1.65(\mathrm{~m}, 2 \mathrm{H}), 1.18-1.32(\mathrm{~m}, 10 \mathrm{H}), 3.36(\mathrm{~s}, 2 \mathrm{H}), 3.73(\mathrm{~s}, 6 \mathrm{H})$, 3.82 (s, 2H). IR (KBr pellets) cm ${ }^{-1}: 3468.13$ (NH str.), 3196.15 (C-H str., aromatic), 3047.63 (C-H str., alkenes), 2922.25 (C-H str., alkane), 1658.84 (C=0 str.), 1600.97 ( $\mathrm{C}=\mathrm{C}$, aromatic), 1462.09 \& 1384.94 (C-H bending, alkane), 1271.13 (C-O-C asym. str.), 1139.97 (C-N), 1107.18 (C-O-C sym. str.), 904.64 (C-H bending, alkenes). MS ES+ (ToF): $\mathrm{m} / \mathrm{z} 347.2\left[\mathrm{M}^{+}+1\right]$. 
$N^{\prime}$-(3-hydroxy-4-methoxybenzylidene)undec-10-enehydrazide (9) $\mathrm{Mp}\left({ }^{\circ} \mathrm{C}\right)$ 104-109; yield 55\%; ${ }^{1} \mathrm{H}$ NMR (400 MHz, DMSO): $\delta 10.99(\mathrm{~s}, 2 \mathrm{H})$, $9.77(\mathrm{~s}, \mathrm{NH}), 6.80-7.03(\mathrm{~m}, 4 \mathrm{H}), 5.89-5.67(\mathrm{~m}, 1 \mathrm{H}), 4.90-4.99(\mathrm{~m}, 2 \mathrm{H})$, 3.80 (s, 3H), 2.16-2.20 (t, 2H), 1.96-1.98 (m, 2H), 1.19-1.62 (m, 10H). IR ( $\mathrm{KBr}$ pellets) $\mathrm{cm}^{-1}: 3471.98$ (NH str.), 3238.59 (OH str.), 3196.15 (C-H str., aromatic), 3053.42 (C-H str., alkenes), 2924.18 (C-H str., alkane), 2360.95 ( $\mathrm{C}=\mathrm{N}$ ), 1656.91 ( $\mathrm{C}=\mathrm{O}$ str.), 1600.97 ( $\mathrm{C}=\mathrm{C}$, aromatic), 1273.06 (C-O-C asym. str.), 1213.27 (C-N), 1122.61 (C-O-C sym. str.), 964.44 (C-H bending, alkenes).

$N^{\prime}$-(4-ethoxy-3-hydroxybenzylidene)undec-10-enehydrazide (10) $\mathrm{Mp}\left({ }^{\circ} \mathrm{C}\right)$ 215-220; yield 65\%; ${ }^{1} \mathrm{H}$ NMR (400 MHz, DMSO): $\delta$ 5.71-5.82 (m, $1 \mathrm{H}), 4.02-4.12(\mathrm{~m}, 2 \mathrm{H}), 3.80(\mathrm{~s}, 3 \mathrm{H}), 6.80-6.99(\mathrm{~m}, 6 \mathrm{H}), 2.00-2.20(\mathrm{~m}$, $2 \mathrm{H}), 1.57-1.64(\mathrm{~m}, 2 \mathrm{H}), 1.19-1.43(\mathrm{~m}, 10 \mathrm{H}), 9.75(\mathrm{~s}, \mathrm{NH}), 10.96(\mathrm{~s}, 2 \mathrm{H})$. IR ( $\mathrm{KBr}$ pellets) $\mathrm{cm}^{-1}: 3435.34$ (NH str.), 3572.29 (OH str.), 3236.66 (C-H str., aromatic), 3076.56 (C-H str., alkenes), 2924.18 (C-H str., alkane), $2333.94(\mathrm{C}=\mathrm{N}), 1658.84$ ( $\mathrm{C}=0$ str.), 1631.83 ( $\mathrm{C}=\mathrm{C}$ str., alkenes), 1600.97 (C=C, aromatic), 1290.42 (C-O-C asym. str.), 1213.27 (C-N), 1122.61 (C-O-C sym. str.), 966.37 (C-H bending, alkenes), 1438.98 and 1392.65 (C-H bending, alkane).

\section{$N^{\prime}$-(3,5-dihydroxybenzylidene)undec-10-enehydrazide (13)}

$\mathrm{Mp}\left({ }^{\circ} \mathrm{C}\right)$ 145-150; Yield 68\%; ${ }^{1} \mathrm{H}$ NMR (400 MHz, DMSO): $\delta 5.00(\mathrm{~m}, 1 \mathrm{H})$, 4.90-4.99 (m, 2H), 7.69-7.76 (m, 4H), 1.90-1.92 (m, 2H), 2.18-2.22 (t, $2 \mathrm{H}), 1.57-1.63(\mathrm{q}, 2 \mathrm{H}), 1.17-1.31(\mathrm{~m}, 10 \mathrm{H}), 9.79(\mathrm{~s}, 1 \mathrm{H}), 11.13(\mathrm{~s}, 1 \mathrm{H})$. \%; IR ( $\mathrm{KBr}$ pellets) $\mathrm{cm}^{-1}$ : 3527.92 (OH str.), 3203.87 (NH str.), 3171.08 (C-H str., aromatic), 2916.47 (C-H str., alkenes), 2850.88 (C-H str., alkane), 1664.64 ( $\mathrm{C}=0$ str.), 1450.52 ( $\mathrm{C}=\mathrm{C}$, aromatic), 1600.97 ( $\mathrm{C}=\mathrm{C}$ str., alkenes), 1161.19 (C-N str.), 858.34 (C-H bending, alkenes).

\section{$\mathrm{N}$-[3-chloro-2-(3-nitrophenyl)-4-oxoazetidin-1-yl] undec-10-} enamide (15)

Bp $\left({ }^{\circ} \mathrm{C}\right)$ 105-110; yield 65\%; ${ }^{1} \mathrm{H}$ NMR $\left(\mathrm{CDCl}_{3}\right)$ : $\delta 8.19(\mathrm{~s}, 1 \mathrm{H}), 6.85-7.67$ (m, 4H), 5.61-5.64 (m, 1H), $5.42(\mathrm{~d}, 1 \mathrm{H}), 5.11(\mathrm{t}, 1 \mathrm{H}), 4.67-4.77(\mathrm{~d}, 2 \mathrm{H})$, 2.50-2.72 (m, 2H), $2.30(\mathrm{t}, 2 \mathrm{H}), 1.50-1.54(\mathrm{~m}, 2 \mathrm{H}), 1.18-1.24(\mathrm{~m}, 10 \mathrm{H}) . \mathrm{IR}$ (KBr pellets) $\mathrm{cm}^{-1}: 3448.84$ (NH str), 2968.55 (C-H str., aliphatic), 1639.55 ( $\mathrm{C}=\mathrm{C}$ alkenes), 1656.91 and 1732.13 ( $\mathrm{C}=0 \mathrm{~s}$ str.), 1529.60 and 1346.36 (N-H bending), 1454.38 ( $\mathrm{C}=\mathrm{C}$, aromatic), 1369.50 ( $\mathrm{N}=0 \mathrm{str}$ ), 615.31 ( $\mathrm{C}-\mathrm{Cl}$ str.).

\section{N-(3-chloro-2-(3-flourophenyl)-4-oxoazetidin-1-yl) undec-10- enamide (16)}

Bp $\left({ }^{\circ} \mathrm{C}\right)$ 118-123; yield 55\%; ${ }^{1} \mathrm{H}$ NMR (DMSO): $\delta 8.16$ (s, $\left.1 \mathrm{H}\right), 6.80-7.35$ $(\mathrm{m}, 4 \mathrm{H}), 5.61-5.64(\mathrm{~m}, 1 \mathrm{H}), 5.40(\mathrm{~d}, 1 \mathrm{H}), 5.07(\mathrm{t}, 1 \mathrm{H}), 4.67-4.77(\mathrm{~d}, 2 \mathrm{H})$, 2.50-2.72 (m, 2H), $2.30(\mathrm{t}, 2 \mathrm{H}), 1.50-1.54(\mathrm{~m}, 2 \mathrm{H}), 1.18-1.24(\mathrm{~m}, 10 \mathrm{H})$ IR ( $\mathrm{KBr}$ pellets) $\mathrm{cm}^{-1}: 3443.05$ ( $\mathrm{NH}$ str.), 2926.11 (C-H str., aliphatic), 1718.63 and 1735.99 ( $\mathrm{C}=0$ str.), 1633.76 ( $\mathrm{C}=\mathrm{C}$ alkenes), $1604.83(\mathrm{~N}-\mathrm{H}$ bending), $1560 \& 1437$ (C=C, aromatic), 1373.36 (C-F str.), 761.91 (C-Cl).

\section{3-methyl-1-(undec-10-enoyl)-1H-pyrazol-5(4H)-one (17)}

Mp $\left({ }^{\circ} \mathrm{C}\right)$ 238-243; Yield 52\%; ${ }^{1} \mathrm{H}$ NMR (DMSO): $\delta$ 5.77- $5.80(\mathrm{~d}, 2 \mathrm{H}$ ), 4.03-4.17 (m, 1H), 2.01-2.18 (m, 2H), $2.34(\mathrm{t}, 2 \mathrm{H}), 1.30-1.34(\mathrm{~m}, 2 \mathrm{H})$, 1.77 (s, 3H), 1.90-2.10 (d, 2H), 1.16-1.29 (m, 10H) IR (KBr pellets) $\mathrm{cm}^{-1} 3421.83$ and 3223.16 (NH str.), 3072.71 (C-H str. alkenes), 2850.88 (C-H str., alkane), 2360.95 (C=N str.), 1656.91 and 1710.92 (C=0 str.), $1442.80\left(\mathrm{CH}_{2}\right.$ bend), 1313.57 (C-N str.).

\section{2-(Dec-9-en-1-yl)-5-methyl-1,3,4-oxadiazole (18)}

$\mathrm{Mp}\left({ }^{\circ} \mathrm{C}\right) 45-61 \%$; yield 65\%; ${ }^{1} \mathrm{H} \mathrm{NMR}\left(\mathrm{CDCl}_{3}\right)$ : $\delta 5.67-5.74(\mathrm{~d}, 2 \mathrm{H}), 4.83-4.93$ (m, 1H), 2.05-2.19 (m, 2H), $2.56(\mathrm{t}, 2 \mathrm{H}), 1.32(\mathrm{~m}, 2 \mathrm{H}), 2.68(\mathrm{~s}, 3 \mathrm{H}), 1.21-$ 1.29 (m, 10H) IR (KBr pellets) $\mathrm{cm}^{-1}: 3076.56$ (C-H str., alkenes), 2928.04 (C-H str., aliphatic), 2254.86 (C=N str.), 1739.85 (C=0 str.), 1641.48 ( $\mathrm{C}=\mathrm{C}$, alkenes), 1458.23 (C-H bending, aliphatic), 976.01 (C-H bending, alkenes).

\section{$N^{\prime}$-acetylundec-10-enehydrazide (19)}

$\mathrm{Mp}\left({ }^{\circ} \mathrm{C}\right)$ 184-189; yield 64\%; ${ }^{1} \mathrm{H}$ NMR $\left(\mathrm{CDCl}_{3}\right): \delta 9.63-9.71(\mathrm{~d}, 1 \mathrm{H}), 9.43-$ $9.45(\mathrm{~d}, 1 \mathrm{H}), 5.68-5.78(\mathrm{~m}, 1 \mathrm{H}), 4.82-4.90(\mathrm{~m}, 2 \mathrm{H}), 2.02-2.43(\mathrm{~m}, 2 \mathrm{H})$, $2.60(\mathrm{t}, 2 \mathrm{H}), 1.50-1.53(\mathrm{~m}, 2 \mathrm{H}), 1.33-1.54(\mathrm{~m}, 10 \mathrm{H}), 1.21(\mathrm{~s}, 3 \mathrm{H})$. IR (KBr pellets) $\mathrm{cm}^{-1}: 3462.34 \& 3221.23$ (NH str.), 3032.20 (C-H str., alkenes), 2856.67 (C-H str., aliphatic), 1720 ( $\mathrm{C}=0$ str.), 1654.98 (C=C, alkenes), 1641.48 (NH bending), 1371.43 (C-H bending, aliphatic), 910.43 (C-H bending, alkenes).

\section{Antimicrobial studies}

"The antimicrobial activity of synthesized derivatives (2-19) was performed against Gram-negative bacteria: E. coli; Gram-positive bacteria: S. aureus, B. subtilis; and fungal strains: A. fumigatus and A. niger by tube dilution method. Ciprofloxacin and fluconazole were used as a standard drug for antibacterial and antifungal activities. The standard and test samples were dissolved in DMSO to give a concentration of $100 \mu \mathrm{g} / \mathrm{ml}$. Dilutions of test and standard compounds were prepared in double strength nutrient broth - I.P. (bacteria) or Sabouraud dextrose broth I.P. (fungi) [33]. The samples were incubated at $37^{\circ} \mathrm{C}$ for $24 \mathrm{hrs}$ (bacteria), at $25^{\circ} \mathrm{C}$ for 7 days (A. niger) and at 37 ${ }^{\circ} \mathrm{C}$ for $48 \mathrm{hr}$ (A. fumigatus), and the results were recorded in terms of minimum inhibitory concentration (MIC) (the lowest concentration of test substance which inhibited the growth of microorganisms) by tube dilution method." [11,34].

\section{QSAR studies}

The QSAR study was carried out to find out the relationship between physicochemical parameters and antimicrobial activity of synthesized undecylenic acid hydrazide derivatives. The structures of synthesized derivatives were first preoptimized with the molecular mechanics force field method $\left(\mathrm{MM}^{+}\right)$included in hyperchem 6.0 (1993) [35], and the resulting geometries were further refined by means of the semiempirical method PM3 (parametric method-3). Gradient norm limit of $0.01 \mathrm{kcal} / \AA$ was utilized for the geometry optimization. TSAR 3.3 software for Windows (2000) [36] was used to calculate physicochemical parameters of lowest energy structures of synthesized derivatives. Further, the regression analysis and development of QSAR models was performed using the TSAR 3.3 software. The predictive powers of the developed models were supported by crossvalidated $\mathrm{r}^{2}\left(\mathrm{q}^{2}\right)$ using leave one out (LOO) cross-validation method [37]. The statistical qualities of equations were further confirmed by the parameters such as standard error of estimate (s), correlation coefficient $(\mathrm{r})$, variance ratio $(\mathrm{F})$ at specified degrees of freedom.

\section{Molecular docking}

Molecular docking studies were carried out to understand the binding pattern of synthesized compounds and to support the data of in vitro antimicrobial activity. The two-dimensional structure of ligand was drawn on ChemBioDraw ultra 12.0, and three-dimensional (3D) coordinates were developed using ChemBio3D ultra 12.0. The energy minimization was carried out by MM2 and finally by RHF/3-21G. Automated docking was used to determine the orientation of inhibitors bound in the active site of bacterial beta-ketoacyl-acyl carrier protein synthase III (FabH; pdb id:3IL7) [29,38]. An incremental construction algorithm method, implemented in the program FlexX embedded LeadIT, was employed. Ligand affinity calculations were performed using hyde (in LeadIT) assessment.

\section{RESULTS AND DISCUSSION}

\section{Spectral data analysis}

The synthesis of the intermediate $(2,3)$ and target compounds (4-19) was performed according to reactions outlined in Schemes 1 and 2. A methanolic solution of undecylenic acid 1 was refluxed in the presence of sulfuric acid to yield the methyl ester undecylenic acid (2). The methyl ester 2 was refluxed with hydrazine hydrate to yield undec10 -ene hydrazide 3 , which was condensed with corresponding aromatic aldehydes/acetophenone to synthesize the target undec10 -ene hydrazide derivatives (4-13). Then, corresponding undec-10enehydrazide derivatives (4-6) was refluxed with chloroacetyl chloride and triethylamine in dioxane to produce azetidinone derivatives (14-16). The undec-10-ene hydrazide 3 was also reacted with ethyl acetoacetate; acetic acid in acetic anhydride and acetic anhydride to yield 


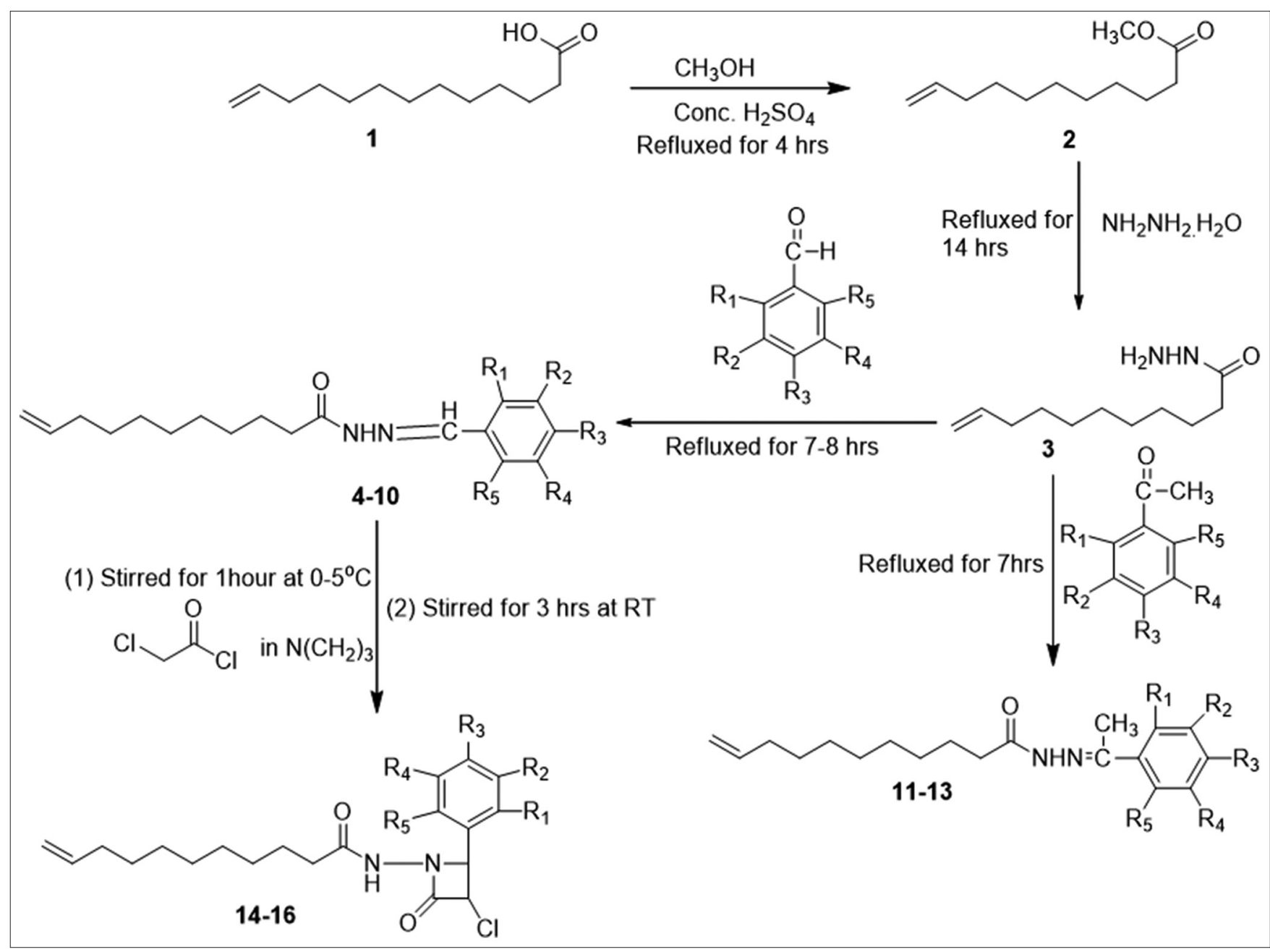

\begin{tabular}{llllll}
\hline Compound & $\mathbf{R}_{\mathbf{1}}$ & $\mathbf{R}_{\mathbf{2}}$ & $\mathbf{R}_{\mathbf{3}}$ & $\mathbf{R}_{\mathbf{4}}$ & $\mathbf{R}_{\mathbf{5}}$ \\
\hline 4 & $\mathrm{H}$ & $\mathrm{H}$ & $\mathrm{H}$ & $\mathrm{H}$ & $\mathrm{H}$ \\
5 & $\mathrm{H}$ & $\mathrm{NO}_{2}$ & $\mathrm{H}$ & $\mathrm{H}$ & $\mathrm{H}$ \\
6 & $\mathrm{H}$ & $\mathrm{F}$ & $\mathrm{HS}$ & $\mathrm{H}$ & $\mathrm{H}$ \\
7 & $\mathrm{H}$ & $\mathrm{OH}$ & $\mathrm{H}$ & $\mathrm{H}$ & $\mathrm{H}$ \\
8 & $\mathrm{H}$ & $\mathrm{OCH}_{3}$ & $\mathrm{OCH}_{3}$ & $\mathrm{H}$ & $\mathrm{H}$ \\
9 & $\mathrm{H}$ & $\mathrm{OH}$ & $\mathrm{OCH}_{3}$ & & $\mathrm{H}$ \\
10 & $\mathrm{H}$ & $\mathrm{OH}$ & $\mathrm{OC}_{2} \mathrm{H}_{5}$ & $\mathrm{H}$ & $\mathrm{H}$ \\
11 & $\mathrm{H}$ & $\mathrm{H}$ & $\mathrm{H}$ & $\mathrm{H}$ & $\mathrm{H}$ \\
12 & $\mathrm{H}$ & $\mathrm{OH}$ & $\mathrm{H}$ & $\mathrm{H}$ & $\mathrm{H}$ \\
13 & $\mathrm{H}$ & $\mathrm{OH}$ & $\mathrm{H}$ & $\mathrm{OH}$ & $\mathrm{H}$ \\
14 & $\mathrm{H}$ & $\mathrm{H}$ & $\mathrm{H}$ & $\mathrm{H}$ & $\mathrm{H}$ \\
15 & $\mathrm{H}$ & $\mathrm{NO}$ & $\mathrm{H}$ & $\mathrm{H}$ & $\mathrm{H}$ \\
16 & $\mathrm{H}$ & $\mathrm{F}$ & $\mathrm{H}$ & $\mathrm{H}$ & $\mathrm{H}$ \\
\hline
\end{tabular}

Scheme 1: Synthetic scheme for synthesis of hydrazone and azetidinone derivatives of undecylenic acid

corresponding hydrazide derivatives (17-19). The physicochemical characteristics of synthesized compounds are presented in Table 1.

Structures of synthesized compounds (2-19) were ascertained on the basis of their ${ }^{1} \mathrm{H}$ NMR and IR spectral data. The presence of two singlet peaks for $\mathrm{NH}$ and $\mathrm{NH}_{2}$ at $\delta 3.88 \mathrm{ppm}$ and $\delta 7.49 \mathrm{ppm}$, respectively, revealed the formation of undec-10-ene hydrazide 3. The appearance of singlet signal ranging from $\delta 7.49$ to $10.72 \mathrm{ppm}$ in the synthesized compounds (4-16) confirmed the presence of $\mathrm{NH}$ of hydrazide derivatives. The appearance of singlet signal of $\mathrm{CH}$ proton in compounds 5 at $\delta 7.92 \mathrm{ppm}$ revealed the formation of $\mathrm{N}=\mathrm{CH}$ bond in the synthesized derivative. The presence of aromatic protons was confirmed by the multiplet signal in the range of $\delta 6.80-8.20 \mathrm{ppm}$. The absence of $-\mathrm{NH}_{2}$ protons in the region of $\delta 3-4 \mathrm{ppm}$ in synthesized compounds (4-19), whereas the presence of same in compound 3 at $\delta 3.88 \mathrm{ppm}$ further confirmed the synthesis of hydrazone and azetidinone derivatives. The appearance of singlet peak of $\mathrm{CH}$ proton at $\delta 1.77 \mathrm{ppm}$ depicted the formation of pyrazole-5-one ring in compound 17 . The appearance of two doublet peak of $\mathrm{NH}$ proton in the range of $\delta$ 9.63-9.71 and 9.43$9.45 \mathrm{ppm}$ revealed the formation of compound 19. The presence of singlet peak at $\delta 3.73$ and 3.80 ppm confirmed the presence of methoxy groups in compound 8 and 10 , respectively.

The presence of the $\mathrm{C}=0$ functional group in compound 2 was indicated by the appearance of a stretching band around $1741 \mathrm{~cm}^{-1}$, which is the characteristic of an ester linkage. Further, the presence of the $\mathrm{C}=0$ stretching of amide group was indicated by the appearance of a band around $1631 \mathrm{~cm}^{-1}(3-20)$. The presence of the $\mathrm{C}=\mathrm{C}$ str. aromatic was 


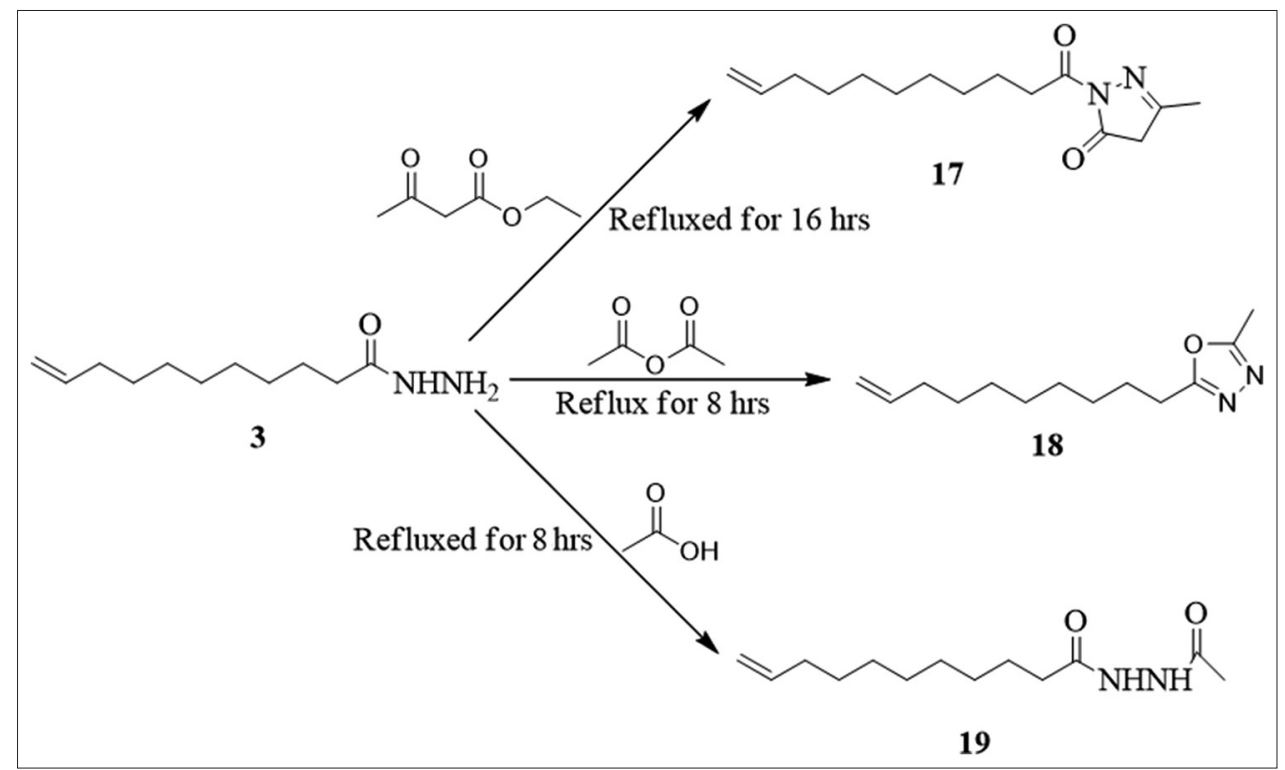

Scheme 2: Synthetic scheme for synthesis of hydrazide derivatives of undecylenic acid

Table 1: Physicochemical properties of synthesized hydrazide derivatives

\begin{tabular}{|c|c|c|c|c|c|}
\hline Compounds & Molecular formula & Molecular weight & $\mathrm{Mp} / \mathrm{Bp}^{*}\left({ }^{\circ} \mathrm{C}\right)$ & $\mathbf{R}_{\mathrm{f}}$ & $\%$ yield \\
\hline 2 & $\mathrm{C}_{12} \mathrm{H}_{22} \mathrm{O}_{2}$ & 198 & $103-108 *$ & $0.71^{\mathrm{a}}$ & 80 \\
\hline 3 & $\mathrm{C}_{11}^{12} \mathrm{H}_{22}^{22} \mathrm{~N}_{2}^{2} \mathrm{O}$ & 198 & $88-93$ & $0.52^{\mathrm{b}}$ & 72 \\
\hline 4 & $\mathrm{C}_{18}^{11} \mathrm{H}_{26}^{22} \mathrm{~N}_{2}^{2} \mathrm{O}$ & 286 & $88-93$ & $0.60^{\mathrm{b}}$ & 64 \\
\hline 5 & $\mathrm{C}_{18} \mathrm{H}_{25} \mathrm{~N}_{3} \mathrm{O}_{3}$ & 331 & $115-120$ & $0.63^{b}$ & 72 \\
\hline 6 & $\mathrm{C}_{18}^{18} \mathrm{H}_{25}^{25} \mathrm{FN}_{2} \mathrm{O}^{3}$ & 304 & $210-215$ & $0.71^{b}$ & 50 \\
\hline 7 & $\mathrm{C}_{18}^{18} \mathrm{H}_{26}^{25} \mathrm{~N}_{2} \mathrm{O}_{2}$ & 302 & $77-82$ & $0.65^{b}$ & 68 \\
\hline 8 & $\mathrm{C}_{20}^{18} \mathrm{H}_{30}^{26} \mathrm{~N}_{2}^{2} \mathrm{O}_{3}^{2}$ & 346 & $210-215$ & $0.67^{b}$ & 50 \\
\hline 10 & $\mathrm{C}_{20} \mathrm{H}_{30} \mathrm{~N}_{2} \mathrm{O}_{3}$ & 346 & $215-220$ & $0.40^{\mathrm{b}}$ & 65 \\
\hline 11 & $\mathrm{C}_{19}^{20} \mathrm{H}_{28}^{30} \mathrm{~N}_{2}^{2} \mathrm{O}^{3}$ & 300 & $120-125$ & $0.67^{b}$ & 50 \\
\hline 12 & $\mathrm{C}_{19}^{19} \mathrm{H}_{28}^{28} \mathrm{~N}_{2}^{2} \mathrm{O}_{2}$ & 316 & $115-120$ & $0.65^{b}$ & 55 \\
\hline 13 & $\mathrm{C}_{19}^{19} \mathrm{H}_{28}^{28} \mathrm{~N}_{2}^{2} \mathrm{O}_{3}^{2}$ & 332 & $145-150$ & $0.53^{\mathrm{e}}$ & 48 \\
\hline 14 & $\mathrm{C}_{20}^{19} \mathrm{H}_{27}^{28} \mathrm{ClN}_{2}^{2} \mathrm{O}_{2}$ & 362 & $113-119^{*}$ & $0.50^{c}$ & 53 \\
\hline 15 & $\mathrm{C}_{20}^{20} \mathrm{H}_{26}^{27} \mathrm{ClN}_{3}^{2} \mathrm{O}_{4}^{2}$ & 407 & $105-110^{*}$ & $0.85^{d}$ & 65 \\
\hline 16 & $\mathrm{C}_{20}^{20} \mathrm{H}_{26}^{26} \mathrm{ClFN}_{3} \mathrm{O}_{2}$ & 380 & $118-123^{*}$ & $0.65^{d}$ & 55 \\
\hline 17 & $\mathrm{C}_{15}^{20} \mathrm{H}_{24}^{26} \mathrm{~N}_{2} \mathrm{O}_{2}^{3}$ & 264 & $238-243$ & $0.69^{b}$ & 52 \\
\hline 19 & $\mathrm{C}_{13}^{13} \mathrm{H}_{24}^{22} \mathrm{~N}_{2}^{2} \mathrm{O}_{2}$ & 240 & 184-189 & $0.80^{\mathrm{b}}$ & 64 \\
\hline
\end{tabular}

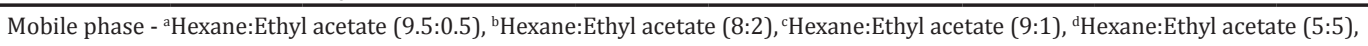

${ }^{\mathrm{e}}$ Chloroform:Hexane:Ethylacetate $(2: 3: 2)$

indicated by the appearance of a stretching band around $1600 \mathrm{~cm}^{-1}$ in compounds (4-20). The appearance of IR band around 3200-3500 $\mathrm{cm}^{-1}$ showed the presence of $\mathrm{NH}$ linkage of amide bond of hydrazide derivatives. The appearance of $\mathrm{C}-\mathrm{F}$, bands at 1294 and $1373 \mathrm{~cm}^{-1}$ in compounds 6 and 16 indicated the presence of fluoro groups in their structures, respectively. In compounds 8, 9 and 10 stretching at around $1271-1290 \mathrm{~cm}^{-1}$ (asymmetric C-O-C stretching) and 1107-1122 $\mathrm{cm}^{-1}$ (symmetric C-O-C stretching) revealed the presence of methoxy and ethoxy groups. Further, the aromatic nitro stretching around $1338 \mathrm{~cm}^{-1}$ (symmetric $\mathrm{NO}_{2}$ stretching) and $1521 \mathrm{~cm}^{-1}$ (asymmetric $\mathrm{NO}_{2}$ stretching) depicted the presence of nitro functional group in synthesized compounds 5 and 15. The presence of two $\mathrm{C}=0$ functional groups were indicated by the appearance of band at 1718.65 and $1735.35 \mathrm{~cm}^{-1}$, which is the characteristics of azetidinones (16). Further, the appearance of IR band around $3200-3300 \mathrm{~cm}^{-1}$ showed the presence of $\mathrm{NH}$ linkage of azetidinone ring. The synthesis of compounds 4 and 8 was further confirmed by molecular ion peak at m/z 287.2 and 347.2 in mass spectra, respectively.

\section{Antimicrobial activity evaluation}

The synthesized undec-10-ene-hydrazide derivatives were evaluated for their in vitro antibacterial activity against Gram-positive S. aureus,
B. subtilis; Gram-negative $E$ coli; and antifungal activity against A. fumigatus and A. niger by tube dilution method [34]. Double strength Nutrient broth I.P. and Sabouraud dextrose broth I.P. have been employed as media for growth of bacterial and fungal cells, respectively [33]. The results of antimicrobial activity (in $\mu \mathrm{M} / \mathrm{ml}$ ) are presented in Table 2 .

In case of $B$. subtilis, compounds $5,8,9,10,14$, and 15 were found to be more active than the other synthesized derivatives having pMIC value in the range of 1.43-1.52 (Table 2). Compound 15 having $m-\mathrm{NO}_{2}$ substituted phenyl ring at third position of 2-azetidinone ring was found to be most active against $B$. subtilis with pMIC value of 1.52 among the synthesized derivatives. Against $S$. aureus, compounds 5, 8, 910,11, and 13 were found to be more active than the other synthesized derivatives having pMIC value in the range of 1.40-1.44 (Table 2). Results of antimicrobial activity depicted the significance of $\mathrm{NO}_{2}(5), \mathrm{OCH}_{3}$, or $\mathrm{OC}_{2} \mathrm{H}_{5}$ and $\mathrm{OH}$ groups $(8,9,10$ and 13$)$ in improving antibacterial activity against $S$. aureus. Further, compounds 8, 11, 13, and 14 were found to be most potent against the Gram-negative bacteria, E. coli having pMIC value 1.44, 1.40, 1.42 and 1.47, respectively (Table 2). Structure activity relationship study of synthesized undecylenic acid 
Table 2: pMIC values of synthesized hydrazides derivatives

\begin{tabular}{|c|c|c|c|c|c|c|c|c|}
\hline \multirow[t]{2}{*}{ Compounds } & \multicolumn{8}{|l|}{ pMIC $(\mu \mathrm{M} / \mathrm{mL})$} \\
\hline & Bacillus subtilis & Staphylococcus aureus & Escherichia coli & $\begin{array}{l}\text { Aspergillus } \\
\text { fumigatus }\end{array}$ & Aspergillus niger & $\mathbf{a b}$ & af & am \\
\hline 1 & 1.17 & 0.87 & 0.87 & 1.17 & 0.87 & 0.97 & 1.02 & 0.99 \\
\hline 2 & 1.20 & 0.90 & 0.90 & 1.20 & 1.20 & 1.0 & 1.20 & 1.08 \\
\hline 3 & 1.20 & 0.90 & 1.20 & 1.20 & 0.90 & 1.1 & 1.05 & 1.08 \\
\hline 4 & 1.37 & 1.06 & 1.37 & 1.37 & 1.06 & 1.26 & 1.21 & 1.24 \\
\hline 5 & 1.43 & 1.43 & 1.12 & 1.43 & 1.12 & 1.33 & 1.28 & 1.31 \\
\hline 6 & 1.39 & 1.39 & 1.09 & 1.39 & 1.09 & 1.29 & 1.24 & 1.27 \\
\hline 7 & 1.08 & 1.08 & 1.08 & 1.39 & 1.39 & 1.08 & 1.39 & 1.20 \\
\hline 8 & 1.44 & 1.44 & 1.44 & 1.39 & 1.39 & 1.44 & 1.39 & 1.42 \\
\hline 9 & 1.43 & 1.43 & 1.12 & 1.43 & 1.43 & 1.33 & 1.43 & 1.37 \\
\hline 10 & 1.44 & 1.44 & 1.14 & 1.44 & 1.44 & 1.34 & 1.44 & 1.38 \\
\hline 11 & 1.39 & 1.40 & 1.40 & 1.39 & 1.39 & 1.39 & 1.39 & 1.39 \\
\hline 12 & 1.08 & 1.08 & 1.08 & 1.39 & 1.39 & 1.08 & 1.39 & 1.20 \\
\hline 13 & 1.12 & 1.42 & 1.42 & 1.42 & 1.42 & 1.32 & 1.42 & 1.36 \\
\hline 14 & 1.47 & 1.17 & 1.47 & 1.47 & 1.17 & 1.37 & 1.32 & 1.35 \\
\hline 15 & 1.52 & 1.21 & 1.21 & 1.52 & 1.21 & 1.32 & 1.37 & 1.34 \\
\hline 16 & 1.19 & 1.19 & 1.19 & 1.49 & 1.49 & 1.19 & 1.49 & 1.31 \\
\hline 17 & 1.33 & 1.03 & 1.03 & 1.33 & 1.33 & 1.13 & 1.33 & 1.21 \\
\hline 18 & 1.25 & 0.96 & 0.66 & 1.25 & 1.25 & 0.96 & 1.25 & 1.07 \\
\hline 19 & 1.29 & 0.92 & 1.29 & 1.29 & 1.29 & 1.17 & 1.29 & 1.22 \\
\hline SD & 0.14 & 0.21 & 0.21 & 0.10 & 0.18 & 0.15 & 0.13 & 0.12 \\
\hline Std. & $2.61^{\mathrm{a}}$ & $2.61^{a}$ & $2.61^{\mathrm{a}}$ & $2.64^{\mathrm{b}}$ & $2.64^{\mathrm{b}}$ & 2.61 & 2.64 & 2.62 \\
\hline
\end{tabular}

SD: Standard deviation, a Ciprofloxacin, ${ }^{\mathrm{b}}$ Fluconazole

hydrazide derivatives showed the importance of electron donating groups, viz., $\mathrm{OCH}_{3}(8)$ and $\mathrm{OH}(13)$ inactivity against $E$. coli.

On the other hand in case of $A$. fumigatus, compounds 15 and 16 and were found to be more active than the other synthesized derivatives having pMIC 1.52 and 1.49 (Table 2). SAR study of synthesized derivatives against $A$. fumigatus showed the presence of meta electron withdrawing substituted $\mathrm{NO}_{2}$ and $\mathrm{F}$ phenyl moiety at 2-azetidinone (15 and 16) ring is important for their antifungal activity. Moreover, comparing antifungal activity of different azetidinones revealed the significance of electron withdrawing groups at meta position of phenyl ring (viz., $\mathrm{NO}_{2}$ and $\mathrm{F}$ groups) against $A$. fumigatus. Role of electron withdrawing groups in antifungal activity against $A$. fumigatus is as follow: $\mathrm{NO}_{2}>\mathrm{F}>\mathrm{H}$.

In case of $A$. niger, compound 16 was found to be active than the other synthesized derivatives having pMIC value of 1.49. Analysis of antifungal results indicated the importance of $p$-fluoro phenyl substituted azetidinone (16) moiety in improving antifungal activity against $A$. niger.

\section{Structure activity relationship}

1. The analysis of antimicrobial results indicated that compound having dimethoxy groups eight was endowed with high antimicrobial activity. The importance of electron-donating groups in enhancing the antimicrobial activity is supported by similar results observed by Emami et al. [39].

2. The introduction of $\mathrm{OH}$ group ( 9 and 10 ) in phenyl moiety led to an increased antimicrobial activity (pMIC 1.43 and 1.44, respectively) except $E$. coli. This observation revealed the fact that the presence of an $\mathrm{OH}$ group increases the antifungal activity probably by forming hydrogen bond with the target site. This fact is supported by the observations of Vicini et al. [40], in contrary, compounds 9 and 10 showed less activity against $E$. coli $(\mathrm{pMIC}=1.12$ and 1.14 , respectively).

3. The presence of an electron-withdrawing $\mathrm{NO}_{2}$ group makes the synthesized derivatives ( 5 and 15 ) highly potent antibacterial and antifungal agents. Moreover, the presence of both azitidinone and $\mathrm{NO}_{2}$ moieties in compound 15 (pMIC=1.34) further enhanced the activity as compared to compound $5(\mathrm{pMIC}=1.31)$. The role of an electron-withdrawing group in increasing the antimicrobial potency is similar to the results of Sharma et al. [41].
4. The presence of electron-withdrawing $m$-fluoro phenyl group in azetidinone derivatives 16 enhances the growth inhibition potency against both tested fungal strains, A. fumigatus and A. niger (pMIC=1.49). Whereas, compound 15 having $m$-nitro phenyl group in azetidinone was found be active against A. fumigatus (pMIC=1.52).

5. The replacement of $\mathrm{NH}_{2}$ group in compound 3 with benzylidene (1-13) and 2-azetidinone moieties (13-16) led to a noticeable increase in antimicrobial activity of the synthesized compounds. This may be due to the increase in lipophilicity of the molecules which may allow them to easily penetrate the microbial membrane. Moreover, azitidinone ring containing compounds are well known for their inhibition of cell wall synthesis ability [42].

6. Aforementioned results showed that different types of substitutions are necessary for a molecule to have antibacterial or antifungal properties. Similar types of results were reported by Sortino et al. [43]. The SAR studies are represented in Figs. 1 and 2.

\section{QSAR studies}

\section{Development of ot-QSAR models}

QSAR is one of the most influential methods for the prediction of biological activity of compounds. QSAR technique is also important in finding quantitative relationships between the molecular structure and biological activity of investigated compounds [44]. In this study, we have performed the QSAR studies by Hansch's analysis using the linear free energy relationship (LFER) model described by Hansch and Fujita [45].

In Hansch's approach, structural properties of compounds are calculated in terms of different physicochemical parameters and these parameters are correlated with biological activity through equation using regression analysis. Before using the biological activity data for QSAR study experimentally determined MIC values changed to -log MIC or pMIC (in micromole) to get all the values positive, normal distribution of errors and to get LFER of these data with physicochemical parameters. Further, regression analysis was performed using calculated physicochemical parameters (Table 3) as independent variables and antimicrobial activity values as dependent variables (Table 2 ). The reference drugs ciprofloxacin and fluconazole were not included in model generation as they belong to different structural series.

On the basis of intercorrelation between the independent variables and also their individual correlation with antimicrobial activity 


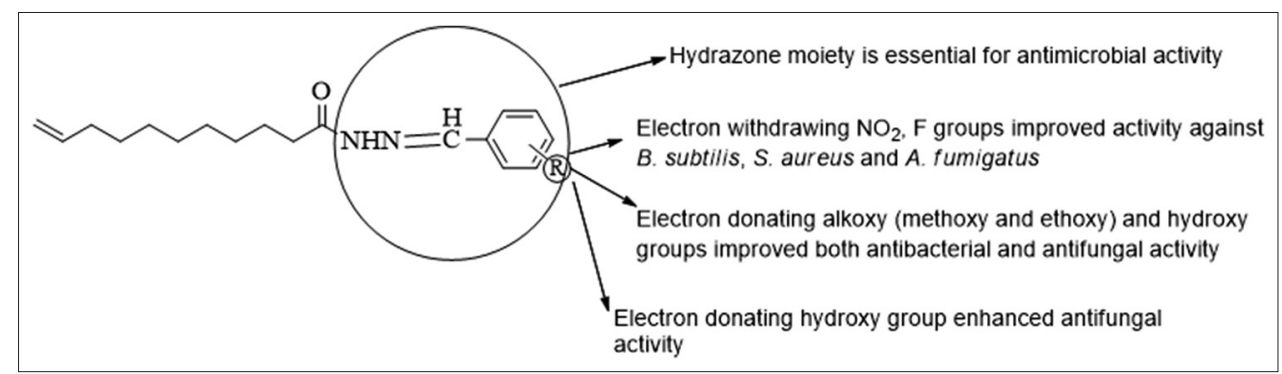

Fig. 1: Structural requirement for the antibacterial and antifungal activities of undecylenic acid hydrazide derivatives

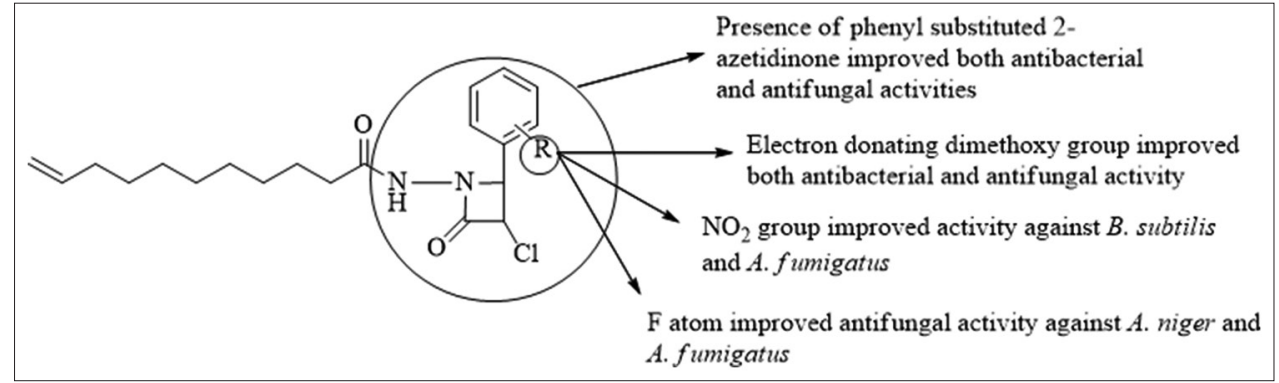

Fig. 2: Structural requirements for the antibacterial and antifungal activities of azetidinone derivatives

Table 3: Values of selected descriptors of synthesized undec-10-enoic acid hydrazide derivatives used in LR and MLR analysis

\begin{tabular}{|c|c|c|c|c|c|c|c|c|c|c|c|c|c|}
\hline Compounds & MM & $\log P$ & ${ }^{0} \chi$ & ${ }^{1} \chi$ & ${ }^{2} \chi$ & ${ }^{2} \chi^{v}$ & $\kappa_{1}$ & $\kappa \alpha_{1}$ & $\mathbf{R}$ & B & W & LUMO & HОМо \\
\hline 1 & 184.31 & 3.42 & 9.94 & 6.27 & 4.66 & 3.34 & 13.00 & 12.37 & 14.09 & 6.89 & 2732.00 & 1.02 & -10.04 \\
\hline 2 & 198.34 & 3.45 & 10.65 & 6.81 & 4.78 & 3.52 & 14.00 & 13.37 & 15.23 & 6.89 & 3554.00 & 1.14 & -10.02 \\
\hline 3 & 198.35 & 2.54 & 10.65 & 6.81 & 4.78 & 3.52 & 14.00 & 13.33 & 15.37 & 6.94 & 3525.00 & 1.01 & -10.03 \\
\hline 4 & 286.46 & 5.10 & 15.18 & 10.33 & 7.80 & 5.15 & 19.05 & 17.71 & 20.49 & 3.47 & 7958.00 & -0.32 & -8.97 \\
\hline 5 & 331.46 & 5.05 & 17.62 & 11.63 & 9.34 & 5.59 & 22.04 & 20.27 & 21.41 & 3.48 & 8954.00 & -1.23 & -9.48 \\
\hline 6 & 304.45 & 5.24 & 16.05 & 10.72 & 8.44 & 5.30 & 20.05 & 18.64 & 20.49 & 3.47 & 7958.00 & -0.38 & -9.02 \\
\hline 7 & 302.46 & 4.81 & 16.05 & 10.72 & 8.44 & 5.34 & 20.05 & 18.67 & 21.03 & 3.47 & 8455.00 & -0.24 & -8.82 \\
\hline 8 & 346.52 & 4.59 & 18.33 & 12.21 & 9.32 & 5.86 & 23.04 & 21.62 & 23.86 & 3.51 & 12478.00 & -0.14 & -8.36 \\
\hline 9 & 332.49 & 4.56 & 17.62 & 11.67 & 9.12 & 5.67 & 22.04 & 20.62 & 22.72 & 3.47 & 10756.00 & -0.20 & -8.52 \\
\hline 10 & 346.52 & 4.90 & 18.33 & 12.17 & 9.50 & 5.90 & 23.04 & 21.62 & 23.97 & 3.47 & 12688.00 & -0.17 & -8.48 \\
\hline 11 & 300.49 & 4.73 & 16.05 & 10.74 & 8.32 & 5.55 & 20.05 & 18.71 & 21.71 & 3.62 & 9170.00 & -0.07 & -9.08 \\
\hline 12 & 316.49 & 4.45 & 16.92 & 11.13 & 8.96 & 5.73 & 21.04 & 19.67 & 22.24 & 3.62 & 9688.00 & -0.16 & -9.06 \\
\hline 13 & 332.49 & 4.16 & 17.79 & 11.54 & 9.48 & 5.88 & 22.04 & 20.62 & 22.78 & 3.66 & 10212.00 & -0.14 & -8.94 \\
\hline 14 & 362.94 & 4.87 & 18.07 & 12.15 & 9.96 & 6.96 & 21.30 & 19.83 & 22.63 & 2.63 & 9860.00 & -0.02 & -9.68 \\
\hline 15 & 407.94 & 4.83 & 20.52 & 13.45 & 11.49 & 7.40 & 24.27 & 22.36 & 23.54 & 2.63 & 10926.00 & -1.31 & -10.04 \\
\hline 16 & 380.93 & 5.01 & 18.94 & 12.54 & 10.60 & 7.10 & 22.29 & 20.75 & 22.63 & 2.63 & 9860.00 & -0.29 & -9.69 \\
\hline 17 & 264.41 & 3.78 & 14.09 & 9.15 & 7.46 & 5.06 & 17.05 & 16.17 & 18.40 & 3.63 & 5842.00 & 0.02 & -9.90 \\
\hline 18 & 222.37 & 3.94 & 11.64 & 7.83 & 6.05 & 4.16 & 14.06 & 13.90 & 16.31 & 3.60 & 4173.00 & -0.02 & -9.98 \\
\hline 19 & 240.39 & 2.17 & 12.93 & 8.16 & 6.34 & 4.18 & 17.00 & 16.00 & 17.49 & 6.93 & 5218.00 & 0.57 & -10.05 \\
\hline
\end{tabular}

LUMO: Lowest unoccupied molecular orbital, HOMO: Highest occupied molecular orbital

Table 4: Correlation matrix for MIC $_{\text {aff }}$ with molecular descriptors

\begin{tabular}{|c|c|c|c|c|c|c|c|c|c|c|c|c|c|c|}
\hline & $\log P$ & MR & ${ }^{0} x$ & ${ }^{1} \chi$ & ${ }^{2} \chi$ & ${ }^{3} \chi$ & $\kappa_{1}$ & $\kappa \alpha_{1}$ & $\mathbf{R}$ & B & $\mathbf{W}$ & LUMO & HOMO & aff \\
\hline $\log P$ & 1.000 & & & & & & & & & & & & & \\
\hline MR & 0.801 & 1.000 & & & & & & & & & & & & \\
\hline${ }^{0} \chi$ & 0.751 & 0.988 & 1.000 & & & & & & & & & & & \\
\hline${ }^{1} \chi$ & 0.788 & 0.995 & 0.997 & 1.000 & & & & & & & & & & \\
\hline${ }^{2} \chi$ & 0.760 & 0.975 & 0.992 & 0.990 & 1.000 & & & & & & & & & \\
\hline${ }^{3} \chi$ & 0.522 & 0.806 & 0.876 & 0.850 & 0.912 & 1.000 & & & & & & & & \\
\hline$\kappa_{1}$ & 0.726 & 0.982 & 0.990 & 0.985 & 0.966 & 0.826 & 1.000 & & & & & & & \\
\hline$\kappa \alpha_{1}$ & 0.723 & 0.984 & 0.989 & 0.985 & 0.965 & 0.824 & 0.999 & 1.000 & & & & & & \\
\hline $\mathrm{R}^{1}$ & 0.749 & 0.989 & 0.976 & 0.979 & 0.951 & 0.774 & 0.983 & 0.987 & 1.000 & & & & & \\
\hline B & -0.871 & -0.869 & -0.836 & -0.865 & -0.870 & -0.718 & -0.781 & -0.791 & -0.824 & 1.000 & & & & \\
\hline W & 0.722 & 0.966 & 0.951 & 0.954 & 0.913 & 0.720 & 0.969 & 0.977 & 0.988 & -0.771 & 1.000 & & & \\
\hline LUMO & -0.760 & -0.819 & -0.819 & -0.828 & -0.840 & -0.744 & -0.795 & -0.789 & -0.750 & 0.836 & -0.697 & 1.000 & & \\
\hline HOMO & 0.580 & 0.620 & 0.543 & 0.567 & 0.466 & 0.149 & 0.619 & 0.631 & 0.688 & -0.478 & 0.736 & -0.339 & 1.000 & \\
\hline Aff & 0.768 & 0.971 & 0.981 & 0.983 & 0.989 & 0.883 & 0.956 & 0.953 & 0.944 & -0.866 & 0.898 & -0.837 & 0.468 & 1.000 \\
\hline
\end{tabular}

LUMO: Lowest unoccupied molecular orbital, HOMO: Highest occupied molecular orbital 
Tables 4 and 5, different probable combinations of parameters were subjected to linear regression (LR) and multiple LR analysis. Out of hundreds of equations generated, some of the best QSAR equations having significant statistical values are selected. These equations were generated in stepwise manner by forward selection method starting with best single variable and adding further significant variable according to their contribution to the model that leads to the smallest standard deviation (s) until there is no other variable outside the equation that satisfies the selection criteria.

The different physicochemical parameters, viz., topological, electronic, thermodynamic, and spatial [45-51], were quantified using TSAR 3.3 software (2000) for synthesized derivatives are summarized in Table 3.

In view of above facts, a data set of 19 synthesized undecylenic acid hydrazide derivatives was used for model development. The predictive powers of derived QSAR models were confirmed by LOO method [37], where a model is built with $\mathrm{N}-1$ compounds and $\mathrm{N}^{\text {th }}$ compound is predicted. Each compound is eliminated for model derivation and predicted in turn. The same procedure is repeated after elimination of another compound until all the compounds have been eliminated once.

A correlation matrix constructed for antibacterial activity against A. fumigatus is presented in Table 4 . Both high and low colinearity was observed between different physicochemical properties. A highest interrelationship was observed between ${ }^{1} \chi$ and ${ }^{0} \chi \quad(r=0.997)$, and lowest interrelationship was observed between ${ }^{3} \chi$ and highest energy occupied molecular orbital (HOMO) $(r=0.149)$. The correlations of different parameters with antimicrobial activities are presented in Table 5. A significant correlation ( $r>0.7$ ) was observed against all tested microbial strains with most of selected parameters except HOMO (Table 5).

ot-QSAR model for antibacterial activity against $S$. aureus pMICsa $=0.181 \mathrm{~W}+1.175$

$\mathrm{n}=19 \quad \mathrm{r}=0.839 \quad \mathrm{q}^{2}=0.682 \quad \mathrm{~s}=0.120 \quad \mathrm{~F}=40.457$

ot-QSAR model (Eq. 1) showed that antibacterial activity of $S$. aureus is positively correlated with Weiner topological index (W). This can be clearly seen from Table 3, compounds 8, 9 and 10 with high W values have highest antibacterial activity (pMICsa=1.43-1.44) (Table 2), whereas in case of compounds 1-3 with low $\mathrm{W}$ values have lowest antibacterial activity (pMICsa range=0.87-0.90). Further, for $S$. aureus biparametric model (Eq. 2) was developed by combination $\mathrm{W}$ and HOMO, and there is slight increase in value of $r$ (from 0.839 [Eq. 1] to 0.857 [Eq. 2]) and $\mathrm{q}^{2}$ (from 0.683 [Eq. 1] to 0.707 [Eq. 2]), thus increase in predictability QSAR models. Further, equation 2 revealed that, against $S$. aureus antibacterial of activity of synthesized derivatives enhances by increase in the value of $\mathrm{W}$ and HOMO.
pMICsa $=0.139 \mathrm{~W}+0.056 \mathrm{HOMO}+1.175$

$\mathrm{n}=19 \quad \mathrm{r}=0.857 \quad \mathrm{q}^{2}=0.707 \quad \mathrm{~s}=0.117 \quad \mathrm{~F}=22.234$

Compounds 8, 9, and 10 have highest activity values $(1.44,1.43$, and 1.44, respectively; Table 2) with highest HOMO values, i.e., $-8.36,-8.52$, and -.8 .48 (lowest negative value), respectively (Table 3 ). On the other side, compounds 1-3 (Table 2) have lowest pMICsa values with lowest HOMO values (highest negative values). The values of rand $\mathrm{q}^{2}$ for Eq. 2 are 0.857 and 0.707 , which means that the resulted QSAR model could explain and predict $85.7 \%$ and $70.7 \%$ of variances, respectively.

ot-QSAR model for antibacterial activity against $E$. coli pMICec $=0.127 \mathrm{R}+1.162$

$n=19 \quad \mathrm{r}=0.604 \quad \mathrm{q}^{2}=0.256 \quad \mathrm{~s}=0.173 \quad \mathrm{~F}=9.740$

In case of E. coli developed, QSAR model (Eq. 3) showed positive correlation with Randic topological index (R). Compounds 8, 11, 13 , and 14 showed highest activity (pMIC range=1.40-1.47) against E. coli comprising high values of R, i.e., 23.86, 21.71, 22.78, and 22.63, respectively. Whereas, compounds 1,2 , and 18 showed least activity against E. coli (Table 2) with low values of R (Table 3).

In general, when $\mathrm{q}^{2}$ is larger than 0.5 , the model is considered to have sound predictive power. However, several studies recommended that a high $\mathrm{q}^{2}$ appear to be a necessary, but not sufficient, condition for a model to have a highly accurate predictive power [52]. Consequently, various other statistical approaches were used to validate the robustness and the practical applicability of the developed QSAR models. To demonstrate that the resulted equations have good prediction of antimicrobial activity of selected hydrazide derivatives, some different methods of evaluation of model performance have been used. Here, $\mathrm{r}^{2}$, which presents the explained variance for given set, was used to determine the goodness of model's fit performance. Moreover, low residual values indicated that experimental and predicted antimicrobial activities are very close to each other also confirmed the robustness of developed models (Tables 6 and 7).

ot-QSAR model for antifungal activity against A. fumigatus

$\mathrm{pMIC}_{\text {aff }}=0.099^{2} \chi+1.366$

$\mathrm{n}=19 \quad \mathrm{r}=0.989 \quad \mathrm{q}^{2}=0.969 \quad \mathrm{~s}=0.015 \quad \mathrm{~F}=776.988$

Developed QSAR model (Eq. 4) revealed that antifungal activity of synthesized derivatives is directly proportional to second order molecular connectivity index $\left({ }^{2} \chi\right)$ against $A$. fumigatus. Compounds 14 , 15 , and 16 demonstrated highest potency (pMIC values 1.47, 1.52, and 1.49 , respectively; Table 2$)$ have highest value of ${ }^{2} \chi(9.96,11.49$, and

Table 5: Correlation of different molecular descriptors with antimicrobial activity of undecanoic acid derivatives

\begin{tabular}{|c|c|c|c|c|c|c|c|c|}
\hline Descriptor & Bacillus subtilis & Staphylococcus aureus & Escherichia coli & $\begin{array}{l}\text { Aspergillus } \\
\text { fumigatus }\end{array}$ & Aspergillus niger & $\mathbf{a b}$ & af & am \\
\hline Log P & 0.387 & 0.683 & 0.226 & 0.768 & 0.316 & 0.547 & 0.534 & 0.608 \\
\hline MR & 0.461 & 0.800 & 0.569 & 0.971 & 0.580 & 0.792 & 0.807 & 0.898 \\
\hline${ }^{0} \chi$ & 0.454 & 0.779 & 0.554 & 0.981 & 0.582 & 0.775 & 0.814 & 0.889 \\
\hline${ }^{1} \chi$ & 0.467 & 0.783 & 0.550 & 0.983 & 0.575 & 0.778 & 0.809 & 0.889 \\
\hline${ }^{2} \chi$ & 0.432 & 0.730 & 0.510 & 0.989 & 0.568 & 0.725 & 0.808 & 0.850 \\
\hline${ }^{3} \chi$ & 0.282 & 0.525 & 0.372 & 0.883 & 0.517 & 0.520 & 0.731 & 0.672 \\
\hline $\mathrm{K} \alpha_{1}$ & 0.448 & 0.824 & 0.572 & 0.953 & 0.612 & 0.803 & 0.824 & 0.913 \\
\hline $\mathrm{R}^{1}$ & 0.426 & 0.819 & 0.604 & 0.944 & 0.644 & 0.806 & 0.841 & 0.922 \\
\hline B & 0.392 & 0.646 & 0.283 & 0.866 & 0.521 & 0.562 & 0.721 & 0.693 \\
\hline W & 0.449 & 0.839 & 0.582 & 0.898 & 0.638 & 0.812 & 0.819 & 0.918 \\
\hline LUMO & 0.488 & 0.643 & 0.242 & 0.837 & 0.324 & 0.577 & 0.573 & 0.646 \\
\hline HOMO & 0.169 & 0.737 & 0.386 & 0.468 & 0.506 & 0.579 & 0.546 & 0.637 \\
\hline
\end{tabular}

LUMO: Lowest unoccupied molecular orbital, HOMO: Highest occupied molecular orbital 
10.60, respectively; Table 3). Further, the presence of predicted and observed values (Fig. 3) close to each other confirmed the robustness of developed QSAR Eq. 4. Moreover, the presences of residual values on both side of zero revealed there is no systemic error exists in developed QSAR model (Fig. 4 and Table 6).

\section{ot-QSAR model for antifungal activity against $A$. niger}

pMICan $=0.117 \mathrm{R}+1.254$

(Eq. 5)

$n=19 \quad \mathrm{r}=0.644 \quad \mathrm{q}^{2}=0.376 \quad \mathrm{~s}=0.143 \quad \mathrm{~F}=12.021$

In case of A. niger developed QSAR model (Eq. 5) indicated the importance of Randic topological index (R) and the results are similar as in case of E. coli. In present both cases (Eqs. 3 and 5) value of $r$ is less, demonstrated that predictability of developed QSAR model is less as compared to other developed QSAR models, where values of $r$ are more (Eqs. 1, 2 and 4).

\section{Development of mt-QSAR models}

"According to the above ot-QSAR models one should use five different equations with different errors to predict the activity of a new compound against the five microbial species. The $o t$-QSAR models, which are almost in all the literature, become unpractical or at less complicated to use when we have to predict to each compound results for more than one target. In these cases, we have to develop one ot-QSAR for each target. However, recently the interest has been increased in the development of $m t$-QSAR models. In opposition to ot-QSAR, the $m t$-QSAR model is a single equation that considers the nature of molecular descriptors which are common and essential for describing the antibacterial and antifungal activity [53-57]." Methods used to calculate average values of antibacterial [pMIC $_{\mathrm{ab}}=\mathrm{pMIC}_{\mathrm{bs}}+\mathrm{pMIC}_{\mathrm{sa}}+\mathrm{pMIC}_{\mathrm{ec}} / 3$ ], antifungal $\left[\mathrm{pMIC}_{\mathrm{af}}=\mathrm{pMIC}_{\mathrm{an}}+\mathrm{pMIC}_{\mathrm{aff}} / 2\right.$ ] and overall antimicrobial activities $\left[\mathrm{pMIC}_{\mathrm{am}}=\mathrm{pMIC}_{\mathrm{bs}}+\mathrm{pMIC}_{\mathrm{sa}}+\mathrm{pMIC}_{\mathrm{ec}}+\mathrm{pMIC}_{\mathrm{an}}+\mathrm{pMIC}_{\mathrm{aff}} / 5\right]_{\text {] }}$ and $m t-\mathrm{QSAR}$ models are described in our previous studies [5-10,58].

\section{mt-QSAR model for antibacterial activity}

$\mathrm{pMIC}_{\mathrm{ab}}=0.122 \mathrm{~W}+1.214$

$\mathrm{n}=19 \quad \mathrm{r}=0.812 \quad \mathrm{q}^{2}=0.631 \quad \mathrm{~s}=0.090 \quad \mathrm{~F}=33.003$

Similar to $S$. aureus (Eq. 1), overall antibacterial activity is also governed by $\mathrm{W}$ (Eq. 6). Compound 8 with maximum antibacterial potency $\left(\mathrm{pMIC}_{\mathrm{ab}}=1.44\right)$ (Table 2) have the highest value of $\mathrm{W}$ (12478)

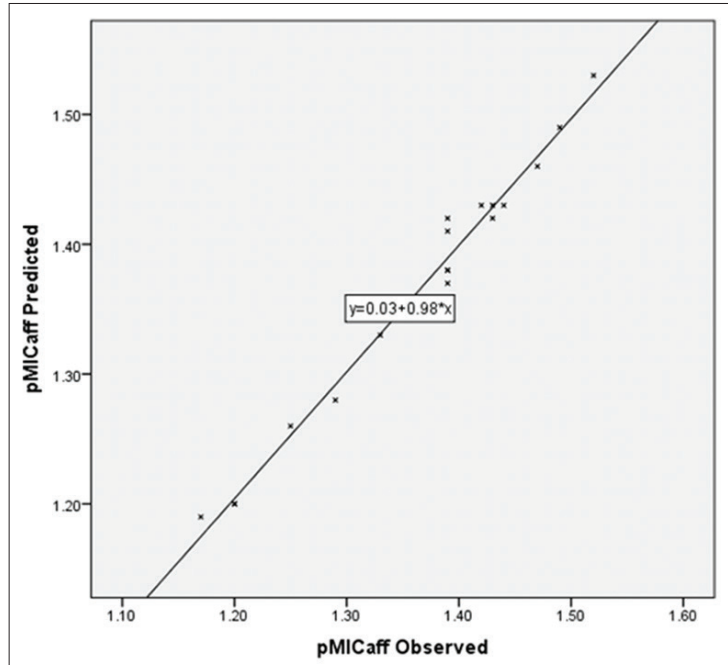

Fig. 3: Plot of predicted pMIC ${ }_{\text {aff }}$ values against observed pMIC ${ }_{\text {aff }}$ values for the model developed by Eq. 4

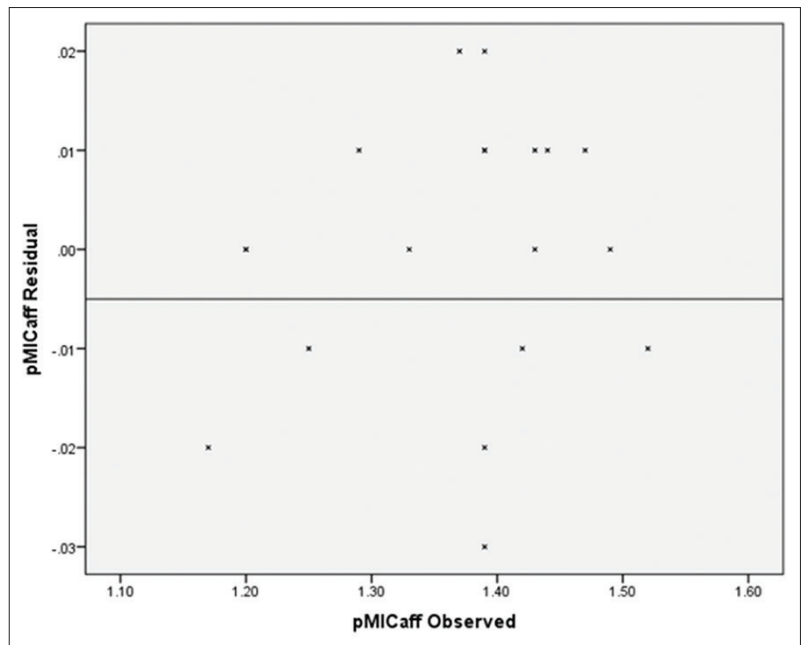

Fig. 4: Plot of residual pMIC ${ }_{\text {aff }}$ values against observed pMIC values for the model developed by Eq. 4

Table 6: Comparison of observed and predicted antibacterial and antifungal activity obtained by ot - QSAR models

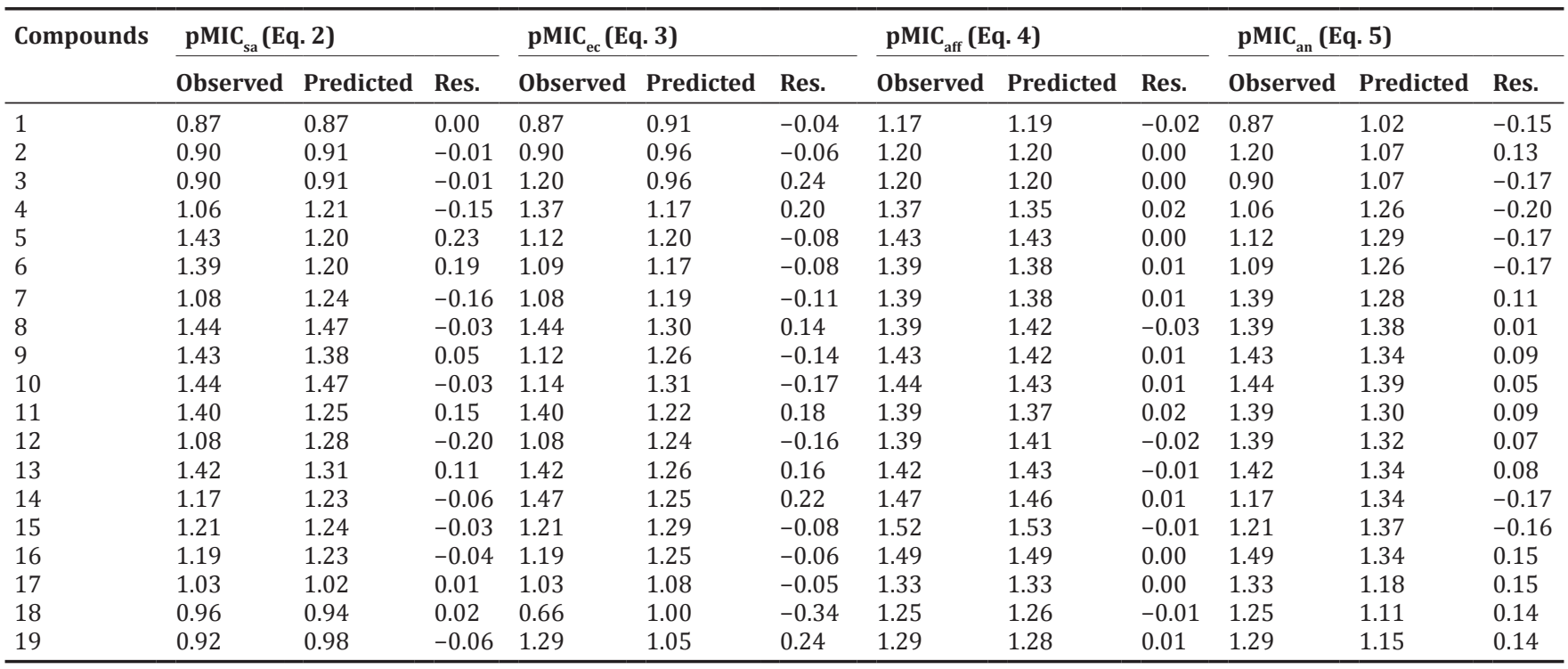

MIC: Minimum inhibitory concentration, QSAR: Quantitative structure-activity relationship 
(Table 3) among the synthesized compounds. On the other side, compounds 1 and 18 with lowest pMICab values (pMIC $\mathrm{pab}_{2 \mathrm{~b}}=0.97$ and 0.96) (Table 2) have a minimum value of $W$, i.e., 2732 and 4173 (Table 3).

mt-QSAR model for antifungal activity

pMIC $_{\text {af }}=0.106 \mathrm{R}+1.311$

$\mathrm{n}=19 \quad \mathrm{r}=0.841 \quad \mathrm{q}^{2}=0.636 \quad \mathrm{~s}=0.070 \quad \mathrm{~F}=41.189$

In the case of antifungal activity, developed $m t$-QSAR model (Eq. 7) depicted the importance of R. Compound 16 was found to be most potent antifungal compound (pMICaf=1.49) (Table 2) among the synthesized derivatives comprising a high value of R (22.63) (Table 3). Whereas, compound 1 (pMICaf=1.02) (Table 2) with lowest antifungal potency have the lowest value of R (14.09) (Table 3).

mt-QSAR model for overall antimicrobial activity

pMIC $_{\text {am }}=0.116 \mathrm{R}+1.252$

$\mathrm{n}=19 \quad \mathrm{r}=0.922 \quad \mathrm{q}^{2}=0.836 \quad \mathrm{~s}=0.050 \quad \mathrm{~F}=92.925$

Developed QSAR model (Eq. 8) revealed that overall antimicrobial activity of synthesized derivative is positively correlated with $\mathrm{R}$. Compound 8 was found to be most potent (pMICam=1.42) (Table 2) among synthesized derivatives with a high value of $R$ (23.86) (Table 3). On the other side, compound 1 with least potency (pMIC=0.99) (Table 2) have lowest R value (14.09) (Table 3). Further, the presence of predicted and observed value (Fig. 5) close to each other confirmed the robustness of developed QSAR Eq. 4. Moreover, the presence of residual values on both side of zero revealed no systemic error exists in developed QSAR model (Fig. 6 and Table 7).

Topological index (or molecular structure descriptor) is a numerical value associated with chemical molecule used for correlation of chemical structure with various physical properties, chemical reactivity or biological activity. One of the most important topological indexes is Randic index. It is also known as branching and connectivity index. It characterizes the branching in a chemical molecule. The mathematical formula for calculation of Randic index is:

$$
R=R(G)=\sum_{u-v} \frac{1}{\sqrt{d_{u}(G) d_{v}(G)}}
$$

$\mathrm{u}$ and $\mathrm{v}$ represent the vertices of the molecular graph $(\mathrm{G})$, vertices of the molecular graph represents a carbon atom. The number of

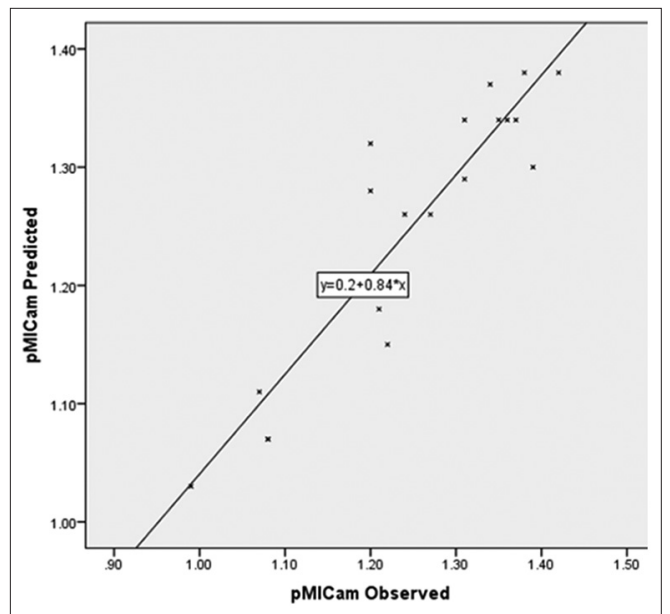

Fig. 5: Plot of predicted pMIC ${ }_{\text {am }}$ values against observed pMIC ${ }_{a m}$ values for the model developed by Eq. 8

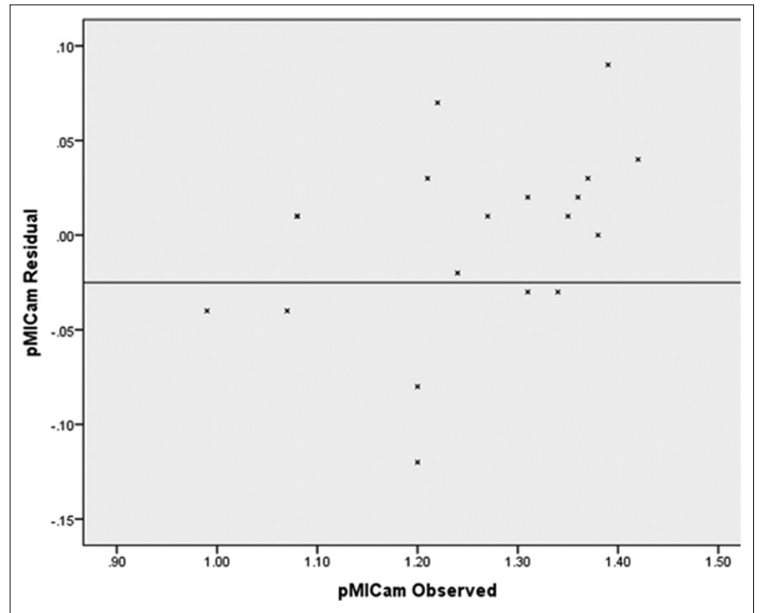

Fig. 6: Plot of residual pMIC $\mathrm{am}_{\mathrm{m}}$ values against observed pMIC values for the model developed by Eq. 8

Table 7: Comparison of observed and predicted antimicrobial activity obtained by $m t-Q S A R$ models

\begin{tabular}{|c|c|c|c|c|c|c|c|c|c|}
\hline \multirow[t]{2}{*}{ Compounds } & \multicolumn{3}{|c|}{$\mathrm{pMIC}_{\mathrm{ab}}$ (Eq. 6) } & \multicolumn{3}{|c|}{$\mathrm{pMIC}_{\mathrm{af}}$ (Eq. 7) } & \multicolumn{3}{|c|}{$\mathrm{pMIC}_{\mathrm{am}}$ (Eq. 8) } \\
\hline & Observed & Predicted & Res. & Observed & Predicted & Res. & Observed & Predicted & Res. \\
\hline 1 & 0.97 & 1.00 & -0.03 & 1.02 & 1.10 & -0.08 & 0.99 & 1.03 & -0.04 \\
\hline 3 & 1.10 & 1.03 & 0.07 & 1.05 & 1.14 & -0.09 & 1.08 & 1.07 & 0.01 \\
\hline 4 & 1.26 & 1.21 & 0.05 & 1.21 & 1.32 & -0.11 & 1.24 & 1.26 & -0.02 \\
\hline 5 & 1.33 & 1.25 & 0.08 & 1.28 & 1.35 & -0.07 & 1.31 & 1.29 & 0.02 \\
\hline 6 & 1.29 & 1.21 & 0.08 & 1.24 & 1.32 & -0.08 & 1.27 & 1.26 & 0.01 \\
\hline 7 & 1.08 & 1.23 & -0.15 & 1.39 & 1.33 & 0.06 & 1.20 & 1.28 & -0.08 \\
\hline 8 & 1.44 & 1.39 & 0.05 & 1.39 & 1.43 & -0.04 & 1.42 & 1.38 & 0.04 \\
\hline 9 & 1.33 & 1.32 & 0.01 & 1.43 & 1.39 & 0.04 & 1.37 & 1.34 & 0.03 \\
\hline 10 & 1.34 & 1.40 & -0.06 & 1.44 & 1.43 & 0.01 & 1.38 & 1.38 & 0.00 \\
\hline 11 & 1.39 & 1.26 & 0.13 & 1.39 & 1.36 & 0.03 & 1.39 & 1.30 & 0.09 \\
\hline 12 & 1.08 & 1.28 & -0.20 & 1.39 & 1.37 & 0.02 & 1.20 & 1.32 & -0.12 \\
\hline 13 & 1.32 & 1.30 & 0.02 & 1.42 & 1.39 & 0.03 & 1.36 & 1.34 & 0.02 \\
\hline 14 & 1.37 & 1.28 & 0.09 & 1.32 & 1.39 & -0.07 & 1.35 & 1.34 & 0.01 \\
\hline 15 & 1.32 & 1.33 & -0.01 & 1.37 & 1.42 & -0.05 & 1.34 & 1.37 & -0.03 \\
\hline 17 & 1.13 & 1.12 & 0.01 & 1.33 & 1.25 & 0.08 & 1.21 & 1.18 & 0.03 \\
\hline 18 & 0.96 & 1.06 & -0.10 & 1.25 & 1.18 & 0.07 & 1.07 & 1.11 & -0.04 \\
\hline 19 & 1.17 & 1.10 & 0.07 & 1.29 & 1.22 & 0.07 & 1.22 & 1.15 & 0.07 \\
\hline
\end{tabular}

MIC: Minimum inhibitory concentration, QSAR: Quantitative structure-activity relationship 


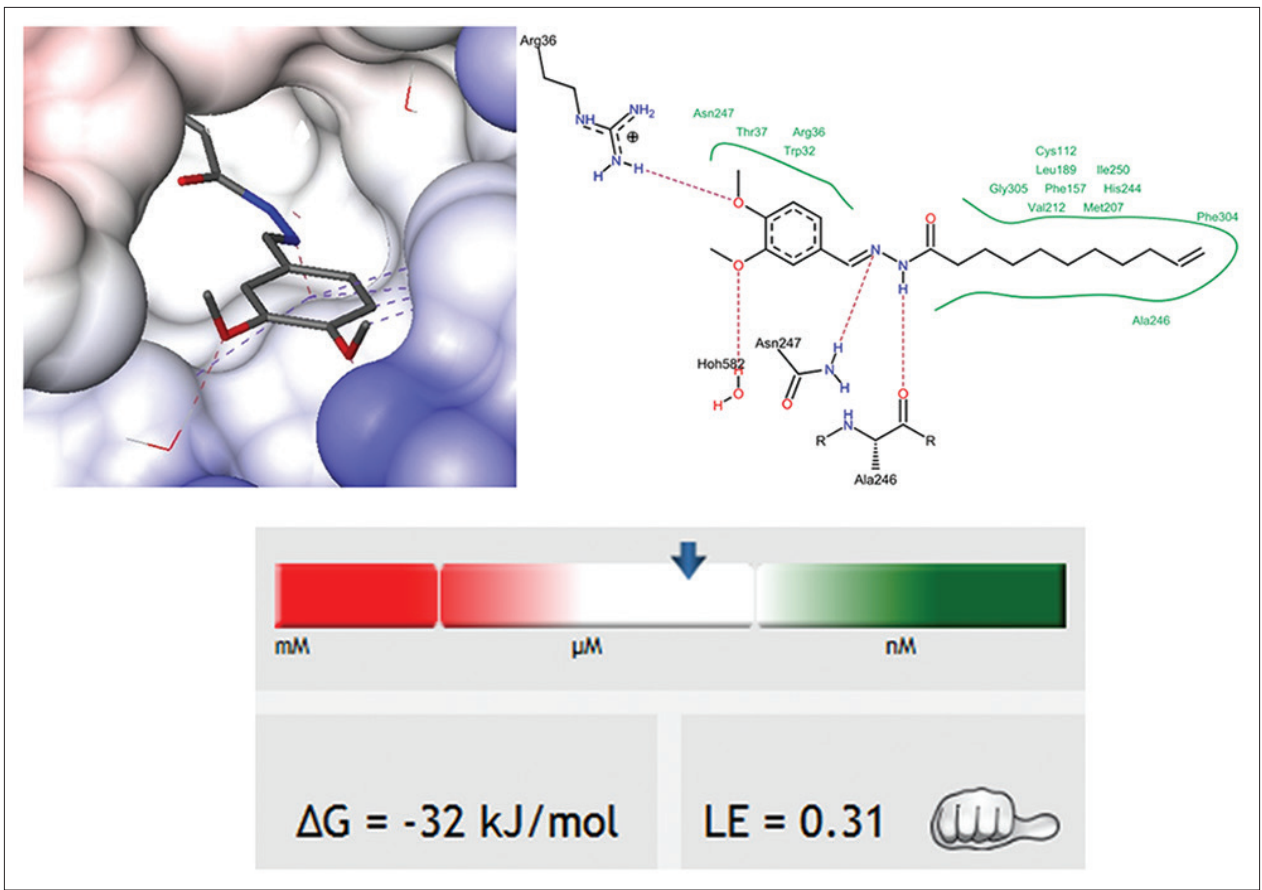

Fig. 7: Pose view of molecular docking with binding pattern and hyde assessment for compound 8

vertices of G adjacent to a given vertex v, is the "degree of vertex" and it is represented by $d_{v}(G)$. Molecular graph technique can be utilized to represent carbon-hydrogen skeleton of an organic compound [59].

\section{Molecular docking evaluation}

Ligand affinity calculations of most potent compound (8) were performed using Hyde (in LeadIT) assessment showed the bettercalculated score as -2.3 . The pose view of conformation with highest docking score $(-13.6762)$, binding energy $\Delta \mathrm{G}(-32 \mathrm{KJ} / \mathrm{mol})$, and ligand affinity $(\mathrm{LE}=31 \mu \mathrm{M})$ found to be better than cocrystallized ligand (Fig. 7). Docking study indicated hydrophobic interaction of deeply inserted aliphatic side chain of ligand with target site FabH. The $\mathrm{N}$-atoms of hydrazide moiety interacts with Ala246 and Asn247 through H-bonding. The $m$ - and $p$-methoxy groups form H-bond with water and side chain of Arg36, respectively, so phenyl moiety oriented in such a way that it can participate in hydrophobic interactions with FabH.

\section{CONCLUSION}

A series of undec-10-enehydrazide derivatives were synthesized and tested against Gram-negative bacteria E. coli, Gram-positive bacteria B. subtilis, S. aureus, fungal strain A. niger and A. fumigatus by tube dilution method. QSAR and molecular modeling studies were performed to correlate antimicrobial activity with structural properties of synthesized molecules. Antimicrobial screening results showed that compound 8 having benzylidine moiety with methoxy groups at meta and para position and compound 16 having 3-chloro2-(3-flourophenyl)-4-oxoazetidin moiety was found to most potent antibacterial and antifungal compounds, respectively. Further, the analysis was performed by the development of multi and otQSAR models. As compared to one target, mt-QSAR models were more effectual in relating the antimicrobial activity of synthesized derivative. In addition, QSAR studies revealed the importance of Randic topology parameter (R) in describing the antimicrobial activity of synthesized hydrazide derivatives. Molecular docking study indicated hydrophobic interaction of deeply inserted aliphatic side chain of the ligand with FabH. The N-atoms of hydrazide moiety interacts with Ala246 and Asn247 through H-bonding. The $m$ - and $p$-methoxy groups (compound 8) form H-bond with water and side chain of Arg36, respectively, so phenyl moiety oriented in such a way that it can participate in hydrophobic interactions with the target site.

\section{REFERENCES}

1. Levy SB. Antibiotic resistance - the problem intensifies. Adv Drug Deliv Rev 2005;57(10):1446-50.

2. Antimicrobial Resistance. World Health Organization. Available from: http://www.who.int/mediacentre/factsheets/fs194/en. [Last accessed on 2017 Feb 27].

3. Ventola CL. The antibiotic resistance crisis: Part 1: Causes and threats. P T 2015;40(4):277-83.

4. Ereaux LP, Craig GE. The oral administration of undecylenic acid in the treatment of psoriasis. Can Med Assoc J 1949;61(4):361-4.

5. Ammendola S, Lembo A, Battistoni A, Tagliatesta P, Ghisalberti C, Desideri A. 10-undecanhydroxamic acid, a hydroxamate derivative of the undecanoic acid, has strong antimicrobial activity through a mechanism that limits iron availability. FEMS Microbiol Lett 2009;294(1):61-7.

6. Narang R, Narasimhan B, Sharma S, Sriram D, Yogeeswari P, Clercq ED, et al. Nicotinic acid benzylidene/phenyl-ethylidene hydrazides: Synthesis, antitubercular, antiviral, antimicrobial evaluation and QSAR studies. Lett Drug Des Discov 2011;8:733-49.

7. Narang R, Narasimhan B, Sharma S, De Clercq E, Pannecouque C, Balzarini J. Substituted naphthalen-1-yl-acetic acid hydrazides: Synthesis, antimicrobial evaluation and QSAR analysis. Med Chem 2013;9(2):249-74.

8. Narang R, Narasimhan B, Sharma S, Sriram D, Yogeeswari P, Clercq ED, et al. Nicotinic acid benzylidene hydrazides: Synthesis, antitubercular, antiviral, antimicrobial evaluation and QSAR studies. Med Chem Res 2012;21(8):1557-76.

9. Narang R, Narasimhan B, Sharma S. Naphthalen-1-yloxy-acetic acid enzylidene/1-phenylethylidene-hydrazide derivatives: Synthesis, antimicrobial evaluation, and QSAR studies. Med Chem Res 2012;21:2526-47.

10. Narang R, Narasimhan B, Sharma S. A review on biological activities and chemical synthesis of hydrazide derivatives. Curr Med Chem 2012;19(4):569-612.

11. Kumar S, Narang R, Nayak SK, Singh SK, Narasimhan B. Synthesis, antimicrobial evaluation and QSAR studies of N'-benzylidene/ (1-phenylethylidene)undec-10-enehydrazides. J Appl Pharm Sci 2016;6(4):104-16.

12. Noshiranzadeh N, Heidari A, Haghi F, Bikas R, Lis T. Chiral lactic hydrazone derivatives as potential bioactive antibacterial agents: 
Synthesis, spectroscopic, structural and molecular docking studies. J Mol Struct 2017;1128:391-9.

13. Wang X, Dai ZC, Chen YF, Cao LL, Yan W, Li SK, et al. Synthesis of 1,2,3-triazole hydrazide derivatives exhibiting anti-phytopathogenic activity. Eur J Med Chem 2017;126:171-82.

14. Nayyar A, Monga V, Malde A, Coutinho E, Jain R. Synthesis, antituberculosis activity, and 3D-QSAR study of 4-(adamantan-1-yl)-2substituted quinolines. Bioorg Med Chem 2007;15(2):626-40.

15. Leite AC, de Lima RS, Moreira DR, Cardoso MV, Gouveia de Brito AC, Farias Dos Santos LM, et al. Synthesis, docking, and in vitro activity of thiosemicarbazones, aminoacyl-thiosemicarbazides and acyl-thiazolidones against Trypanosoma cruzi. Bioorg Med Chem 2006;14(11):3749-57.

16. Gemma S, Kukreja G, Fattorusso C, Persico M, Romano MP, Altarelli M, et al. Synthesis of N1-arylidene-N2-quinolyl- and N2-acrydinylhydrazones as potent antimalarial agents active against CQ-resistant P. Falciparum strains. Bioorg Med Chem Lett 2006;16(20):5384-8.

17. Bhandari SV, Bothara KG, Raut MK, Patil AA, Sarkate AP, Mokale VJ. Design, synthesis and evaluation of anti-inflammatory, analgesic and ulcerogenicity studies of novel S-substituted phenacyl-1,3,4oxadiazole-2-thiol and Schiff bases of diclofenac acid as nonulcerogenic derivatives. Bioorg Med Chem 2008;16(4):1822-31.

18. Varache-Lembège M, Moreau S, Larrouture S, Montaudon D, Robert J, Nuhrich A. Synthesis and antiproliferative activity of aryl- and heteroaryl-hydrazones derived from xanthone carbaldehydes. Eur J Med Chem 2008;43(6):1336-43.

19. Martins F, Santos S, Ventura C, Elvas-Leitão R, Santos L, Vitorino S, et al. Design, synthesis and biological evaluation of novel isoniazid derivatives with potent antitubercular activity. Eur J Med Chem 2014;81:119-38.

20. Yang F, Hu M, Lei Q, Xia Y, Zhu Y, Song X, et al. Nifuroxazide induces apoptosis and impairs pulmonary metastasis in breast cancer model. Cell Death Dis 2015;6:e1701.

21. Jackson Y, Alirol E, Getaz L, Wolff H, Combescure C, Chappuis F. Tolerance and safety of nifurtimox in patients with chronic chagas disease. Clin Infect Dis 2010;51(10):e69-75.

22. Johnson JR, Johnston B, Kuskowski MA. In vitro comparison of nitrofurazone- and silver alloy-coated foley catheters for contactdependent and diffusible inhibition of urinary tract infection-associated microorganisms. Antimicrob Agents Chemother 2012;56(9):4969-72.

23. Safaralizadeh R, Siavoshi F, Malekzadeh R, Akbari MR, Derakhshan MH, Sohrabi MR, et al. Antimicrobial effectiveness of furazolidone against metronidazole-resistant strains of Helicobacter pylori. East Mediterr Health J 2006;12(3-4):286-93.

24. Ningaiah S, Bhadraiah UK, Doddaramappa SD, Keshavamurthy S, Javarasetty C. Novel pyrazole integrated 1,3,4-oxadiazoles: Synthesis, characterization and antimicrobial evaluation. Bioorg Med Chem Lett 2014;24(1):245-8

25. Arya N, Jagdale AY, Patil TA, Yeramwar SS, Holikatti SS, Dwivedi J, et al. The chemistry and biological potential of azetidin-2-ones. Eur J Med Chem 2014;74:619-56.

26. Vilar S, Costanzi S. Predicting the biological activities through QSAR analysis and docking-based scoring. Methods Mol Biol 2012;914:271-84.

27. Meng XY, Zhang HX, Mezei M, Cui M. Molecular docking: A powerful approach for structure-based drug discovery. Curr Comput Aided Drug Des 2011;7(2):146-57.

28. Shoichet BK, McGovern SL, Wei B, Irwin JJ. Lead discovery using molecular docking. Curr Opin Chem Biol 2002;6(4):439-46.

29. Qiu X, Choudhry AE, Janson CA, Grooms M, Daines RA, Lonsdale JT, et al. Crystal structure and substrate specificity of the beta-ketoacylacyl carrier protein synthase III (FabH) from Staphylococcus aureus. Protein Sci 2005;14(8):2087-94.

30. Choi KH, Heath RJ, Rock CO. Beta-ketoacyl-acyl carrier protein synthase III $(\mathrm{FabH})$ is a determining factor in branched-chain fatty acid biosynthesis. J Bacteriol 2000;182(2):365-70.

31. Christensen CE, Kragelund BB, von Wettstein-Knowles $P$, Henriksen A. Structure of the human beta-ketoacyl [ACP] synthase from the mitochondrial Type II fatty acid synthase. Protein Sci 2007;16(2):261-72.

32. Lai CY, Cronan JE. Beta-ketoacyl-acyl carrier protein synthase III $(\mathrm{FabH})$ is essential for bacterial fatty acid synthesis. J Biol Chem 2003;278(51):51494-503.

33. Ministry of Health Department. Pharmacopoeia of India. Vol. 1. New Delhi: Controller of Publications, Ministry of Health Department,
Government of India; 2007. p. 37.

34. Cappuchino JG, Sherman N. Microbiology - A Laboratory Manual. Redwood City: Addison Wesley Longman Inc.; 1999. p. 263.

35. Hypercube, Inc. Hyperchem 6.0. Gainesville: Hypercube, Inc.; 1993.

36. Oxford Molecular Limited. TSAR 3D Version 3.3. Oxford: Oxford Molecular Limited; 2000.

37. Schaper KJ. Free-Wilson-type analysis of non-additive substituent effects on THPB dopamine receptor affinity using artificial neural networks. Quant Struct Act Relat 1999;18:354-60.

38. Gajiwala KS, Margosiak S, Lu J, Cortez J, Su Y, Nie Z, et al. Crystal structures of bacterial FabH suggest a molecular basis for the substrate specificity of the enzyme. FEBS Lett 2009;583(17):2939-46.

39. Emami S, Foroumadi A, Falahati M, Lotfali E, Rajabalian S, Ebrahimi SA, et al. 2-Hydroxyphenacyl azoles and related azolium derivatives as antifungal agents. Bioorg Med Chem Lett 2008;18(1):141-6

40. Vicini P, Zani F, Cozzini P, Doytchinova I. Hydrazones of 1,2-benzisothiazole hydrazides: Synthesis, antimicrobial activity and QSAR investigations. Eur J Med Chem 2002;37(7):553-64.

41. Sharma P, Rane N, Gurram VK. Synthesis and QSAR studies of pyrimido[4,5-d]pyrimidine-2,5-dione derivatives as potential antimicrobial agents. Bioorg Med Chem Lett 2004;14(16):4185-90.

42. Kohanski MA, Dwyer DJ, Collins JJ. How antibiotics kill bacteria: From targets to networks. Nat Rev Microbiol 2010;8(6):423-35.

43. Sortino M, Delgado P, Juárez S, Quiroga J, Abonía R, Insuasty B, et al. Synthesis and antifungal activity of (Z)-5-arylidenerhodanines. Bioorg Med Chem 2007;15(1):484-94.

44. Shahlaei M, Sabet R, Ziari MB, Moeinifard B, Fassihi A, Karbakhsh R. QSAR study of anthranilic acid sulfonamides as inhibitors of methionine aminopeptidase-2 using LS-SVM and GRNN based on principal components. Eur J Med Chem 2010;45(10):4499-508.

45. Hansch C, Fujita T. P-r-p analysis: A method for the correlation of biological activity and chemical structure. J Am Chem Soc 1964;86(8):1616-26.

46. Hansch C, Leo A, Unger SH, Kim KH, Nikaitani D, Lien EJ. "Aromatic" substituent constants for structure-activity correlations. J Med Chem 1973;16(11):1207-16.

47. Kier LB, Hall LH. Molecular Connectivity in Chemistry and Drug Research. New York: Academic Press; 1976.

48. Randic M. Comparative regression analysis. Regressions based on a single descriptor. Croat Chem Acta 1993;66(2):289-312.

49. Balaban AT. Highly discriminating distance-based topological index. Chem Phys Lett 1982;89(2):399-404.

50. Wiener H. Structural determination of paraffin boiling points. J Am Chem Soc 1947;69(1):17-20.

51. Randic M. Characterization of molecular branching. J Am Chem Soc 1975;97(24):6609-15.

52. Oltulu O, Yasar MM, Eroglu E. A QSAR study on relationship between structure of sulfonamides and their carbonic anhydrase inhibitory activity using the eigenvalue (EVA) method. Eur J Med Chem 2009;44(9):3439-44.

53. Prado-Prado FJ, Gonzalez-Diaz H, Vega OM, Ubeira FM, Chou KC. Unified QSAR approach to antimicrobials. Part 3: First multi-tasking QSAR model for Input-Coded prediction, structural back-projection, and complex networks clustering of antiprotozoal compounds. Bioorg Med Chem 2008;16(11):5871-80.

54. González-Díaz H, González-Díaz Y, Santana L, Ubeira FM, Uriarte E. Proteomics, networks and connectivity indices. Proteomics 2008;8(4):750-78

55. González-Díaz H, Vilar S, Santana L, Uriarte E. Medicinal chemistry and bioinformatics - Current trends in drugs discovery with networks topological indices. Curr Top Med Chem 2007;7(10):1015-29.

56. González-Díaz H, Prado-Prado FJ. Unified QSAR and networkbased computational chemistry approach to antimicrobials, part 1: Multispecies activity models for antifungals. J Comput Chem 2008;29(4):656-67.

57. Cruz-Monteagudo M, González-Díaz H, Agüero-Chapín G, Santana L, Borges F, Domínguez ER, et al. Computational chemistry development of a unified free energy Markov model for the distribution of 1300 chemicals to 38 different environmental or biological systems. J Comput Chem 2007;28(11):1909-23.

58. Arora P, Narang R, Bhatia S, Nayak SK, Singh SK, Narasimhan B. Synthesis, molecular docking and QSAR studies of 2, 4-disubstituted thiazoles as antimicrobial agents. J Appl Pharm Sci 2015;5(2):28-42.

59. Gutman I. Degree-based topological indices. Croat Chem Acta 2013;86(4):351-61. 